\title{
1 Natural Lead Isotope Variations in the Atmosphere
}

\author{
2 Malin E. Kylander ${ }^{\mathrm{a} *}$, Jonatan Klaminder ${ }^{\mathrm{b}}$, Richard Bindler $^{\mathrm{c}}$ and Dominik J. Weiss ${ }^{\mathrm{d}, \mathrm{e}}$ \\ ${ }^{a}$ Department of Geology and Geochemistry, Stockholm University, SE-10691 Stockholm, Sweden Tel: +46 \\ (0)8-674 7898; Fax: +46 (0)8-674-7897; malin.kylander@geo.su.se \\ ${ }^{b}$ Department of Ecology and Environmental Sciences, Umeå University, SE-901 87 Umeå, Sweden; \\ jonatan.klaminder@eg.umu.se \\ ${ }^{c}$ Department of Ecology and Environmental Sciences, Umeå University, SE-901 87 Umeå, Sweden; \\ richard.bindler@eg.umu.se \\ $10{ }^{d}$ Department of Earth Science and Engineering, Imperial College London, UK SW7 2AZ; \\ 11 d.weiss@imperial.ac.uk \\ $12{ }^{e}$ Department of Mineralogy, The Natural History Museum, London, UK, SW7 5BD \\ $14 *$ Corresponding author
}

13 


\section{ABSTRACT}

16 Stable lead $(\mathrm{Pb})$ isotope data from pre-contamination peat sections has the potential to

17 contribute to our understanding of earth system processes (e.g., atmospheric circulation,

18 erosion, volcanic activity) in the past. Key questions arise however. Can the $\mathrm{Pb}$ isotopes

19 archived in peat records be used for assessing aerosol dynamics on a hemispheric scale or

20 do they mainly reflect inputs from local soils? What natural $\mathrm{Pb}$ sources are important and

21 do contributions vary over time? In order to answer these questions we have synthesized

22 all available $\mathrm{Pb}$ isotope data from pre-contamination peat sections in Europe, Australia,

23 North America and South America. We specifically examine the spatial and temporal

24 variability of the $\mathrm{Pb}$ isotope records and identify regionally important trends and $\mathrm{Pb}$ 25 sources.

26 A pooling of all available pre-contamination peat data generated an average 27 natural ${ }^{206} \mathrm{~Pb} /{ }^{207} \mathrm{~Pb}$ background ratio of $1.21 \pm 0.05(2 \sigma, \mathrm{n}=300)\left({ }^{206} \mathrm{~Pb} /{ }^{204} \mathrm{~Pb}=18.90 \pm 0.86\right.$, $28{ }^{207} \mathrm{~Pb} /{ }^{204} \mathrm{~Pb}=15.66 \pm 0.10$ and $\left.{ }^{208} \mathrm{~Pb} /{ }^{204} \mathrm{~Pb}=38.74 \pm 0.57, \mathrm{n}=207\right)$. The majority of the

29 records showed limited temporal and compositional agreement, suggesting that the peat

30 record receives mainly inputs from local $(<10 \mathrm{~km})$ and/or regional $(10-500 \mathrm{~km})$ sources.

31 Three-isotope plots also support local and regional control and evidence a wide natural

32 spread at some sites, particularly those located in radiogenic geological settings. A

33 temporally synchronous isotope excursion to values between 1.16-1.18 at sites across

34 Europe ca 4000-3000 B.C. was detected, however. While usually associated with

35 anthropogenic sources, there are indeed natural aerosols having ${ }^{206} \mathrm{~Pb} /{ }^{207} \mathrm{~Pb}$ signatures as

36 low as 1.16 as evidenced in several peat and ice core records globally. Three-isotope

37 plots suggest that this unlikely to be a signal of mineral dust contributions, which tend to 
38 have ${ }^{206} \mathrm{~Pb} /{ }^{207} \mathrm{~Pb}$ ratios $\geq 1.19$, but rather sourced to volcanic emissions. These results

39 stress caution when using estimates of the upper continental crust to constrain natural $\mathrm{Pb}$

40 sources in, e.g., mixing equations. Considering the strong influence from local and

41 regional sources on $\mathrm{Pb}$-containing aerosols in the peat record, the assessment of aerosol

42 dynamics at lower latitudes is likely best achieved using a compliment of archives rather

43 than just polar ice cores, for example.

44

45 Key words: $\mathrm{Pb}$ isotopes; atmospheric deposition; natural; mineral dust; volcano; aerosol 


\section{Introduction}

47 Lead isotopes $\left({ }^{204} \mathrm{~Pb},{ }^{206} \mathrm{~Pb},{ }^{207} \mathrm{~Pb}\right.$ and $\left.{ }^{208} \mathrm{~Pb}\right)$ are a powerful tool in geochemistry having 48 been successfully applied in the fields of, e.g., geochronology (e.g., Allegre et al., 1995;

49 Dickin, 2009) and mantle-crust dynamics (e.g., Hofmann, 1997; Allegre et al., 2008). In

50 the atmospheric sciences $\mathrm{Pb}$ isotopes have been especially effective in tracing the spatial

51 dimensions of atmospheric fallout through the analysis of forest mosses (Rosman et al.,

52 1998), lichens (e.g., Carignan et al., 2002; Spiro et al., 2004) and direct measurements of

53 atmospheric plumes (Simonetti et al., 2004). The temporal dimensions of atmospheric $\mathrm{Pb}$

54 contamination have been established through the analysis of peat and glacial ice (e.g.,

55 papers cited in Table 1) as well as lake sediments (e.g., Shirahata et al., 1980; Brännvall

56 et al., 1999). To date the primary application of $\mathrm{Pb}$ isotopes in these records has been for

57 reconstructing the chronology and sources of atmospheric $\mathrm{Pb}$ contamination.

58 There is, however, further potential to use $\mathrm{Pb}$ isotope data as a tracer of aerosol

59 provenance to provide insight into atmospheric circulation patterns and source area

60 conditions. This type of information is best derived from environmental archives such as

61 ice deposits, which capture a purely atmospheric signal. Ice cores have been used to

62 identify the Iberian Peninsula as the source of $\mathrm{Pb}$ contamination atmospherically

63 transported to, and deposited on, the summit of the Greenland ice sheet during ancient

64 times (Rosman et al., 1997). Similarly, Biscaye et al. (1997) used $\mathrm{Pb}$ isotopes, in

65 combination with clay mineralogy and $\mathrm{Nd}$ and $\mathrm{Sr}$ isotopes, to show that the main source

66 of soil dust deposited at the Greenland summit during the Pleistocene originated from

67 Asian desert areas. Unfortunately, the ice record from Greenland gives limited

68 information about conditions between 8000 to 3000 years ago due to low ice-quality 
69 (Rosman, et al., 1997). Furthermore, as many long-term ice core records are restricted to

70 polar areas and high altitude locations, these (mainly) record aerosols transported in the

71 upper troposphere rather than in the boundary layer (lower 1-2 km of the troposphere)

72 and are more likely to represent an integrated hemispheric signal. Ombrotrophic peat is

73 hydrologically isolated and therefore, like ice, records atmospheric deposition alone. In

74 contrast however, these deposits have a more widespread occurrence, particularly in

75 formerly glaciated regions. In many of these areas peat presents a continuous archive of

76 atmospheric fallout covering the past 8000-10,000 years, and in some cases even longer.

77 Past climatic conditions, inferred from environmental archives worldwide, have

78 revealed a dynamic global climate with periods of rapidly changing oceanic- and

79 atmospheric-circulation patterns during the mid-Holocene (Wanner et al., 2008). Previous

80 studies have already linked changes in atmospheric $\mathrm{Pb}$ isotopes in pre-contamination (i.e.,

81 before the start of human $\mathrm{Pb}$ pollution) peat sections to climatic events (Shotyk, et al.,

82 2001; Klaminder et al., 2003; Kylander et al., 2005) but to what extent peat records are

83 able to identify hemispheric, and even global, atmospheric processes has not been

84 thoroughly evaluated. Does the $\mathrm{Pb}$ isotope composition of peat cores exposed to the same

85 air masses record similar events? Do individual peat archives reflect local $(<10 \mathrm{~km})$,

86 regional $(10-500 \mathrm{~km})$ or even continental and global atmospheric conditions? If the latter

87 is true than these records could be used as archives of large-scale atmospheric circulation

88 patterns; if the former is true, information about small-scale variability could be acquired.

89 What natural $\mathrm{Pb}$ sources are important and do contributions vary over time?

90 To answer these questions we have synthesized all available $\mathrm{Pb}$ isotope data from

91 pre-contamination peat sections in Europe, North America, South America and Australia 
92 with supporting data acquired from ice core records. The objectives of this work are to (i)

93 examine the spatial and temporal variability of natural $\mathrm{Pb}$ aerosols; (ii) establish the

94 geographic scale covered by peat bog records and their applicability to studying global

95 changes; and (iii) examine natural sources of $\mathrm{Pb}$ to the atmosphere.

\section{2. Data Selection}

98 In this synthesis we focus mainly on $\mathrm{Pb}$ isotope records from ombrotrophic peat bogs,

99 supported by records from ice deposits, as both of these archives directly reflect

100 atmospheric deposition. In order to improve on the spatial coverage of the current records

101 three minerotrophic peat bogs have also been included. Lake sediments have been

102 excluded because the natural $\mathrm{Pb}$ entering a lake in the pre-contaminant environment is

103 expected to be dominated by catchment sources. As we focus on aerosols composed of

104 naturally derived $\mathrm{Pb}$ solely, we have only selected records where the authors have been

105 able to unequivocally establish that no human $\mathrm{Pb}$ contribution to the recorded

106 atmospheric signals occurred.

107 The geographic distribution of the sites selected for this synthesis are shown in

108 Figure 1 and include ombrotrophic peat deposits from Sweden (Brännvall et al., 1997;

109 Klaminder et al., 2003), Spain (Kylander et al., 2005), Switzerland (Shotyk et al., 2001),

110 Chile (Bindler and Biester, unpublished) and Canada (Kylander et al., 2009). The

111 minerotrophic sites are located in France (Monna et al., 2004) and Australia (Kylander et

112 al., 2007a). It is believed that the majority of the $\mathrm{Pb}$ signal recorded at these sites is

113 atmospheric in origin. In France this is based on the faithful record of European $\mathrm{Pb}$

114 pollution history, despite the possibility of non-atmospheric contributions, while at the 
115 Australian site the ash contents are low, suggesting an atmospheric origin of mineral

116 matter. Details of the location, temporal coverage of the cores, geological setting and

117 instrumentation used in $\mathrm{Pb}$ isotope measurement for each site are given Table 1 . The ice

118 core records are from the summit of the Greenland ice sheet (GRIP) (Rosman, et al.,

119 1997; Burton et al., 2007), Devon Island (DI), Canada (Zheng et al., 2007) and Antarctica

120 (DC)(Vallelonga et al., 2005) and provide independent records at polar areas. The ice

121 core from Sajama Mountain (Saj), Bolivia (Rosman et al., 2003) is represented by only 2

122 samples dated to 19 and 3 ky B.P. but is included due to the already sparse nature of the

123 data. Age-depth models and the average natural $\mathrm{Pb}$ isotopic background are all taken as

124 established in the original manuscripts.

\section{3. The uncertainties in the peat record}

126 Before interpreting spatial and temporal variations in the peat $\mathrm{Pb}$ isotope records, a brief

127 discussion relating to the uncertainties associated with the analytical methods used for $\mathrm{Pb}$

128 isotope determination and age dating is necessary.

\section{$130 \quad 3.1$ Uncertainties when measuring $\mathbf{P b}$ isotopes}

131 Lead isotopes are commonly measured using quadrupole (Q-) or multi-collector (MC-)

132 ICP-MS and TIMS. Q-ICP-MS analyses of $\mathrm{Pb}$ isotopes routinely achieve precisions of

133 0.2-2.0\% (Begley and Sharp, 1997; Quetel et al., 1997; Becker, 2002), while MC-ICP-

134 MS and TIMS can routinely achieve precisions of 0.002-0.001\% (Walder et al., 1993;

135 Rehkamper and Halliday, 1998; Becker, 2002; Thirlwall, 2002; Weiss et al., 2004;

136 Kylander, et al., 2009). In terms of accuracy, the performance of Q-ICP-MS and MC-

137 ICP-MS for $\mathrm{Pb}$ isotope determination of environmental samples, as quantified against 
138 TIMS measurements, can achieve levels <1.2\% (Begley and Sharp, 1997; Aung et al., 139 2004) and <0.2\% (Belshaw et al., 1998; White et al., 2000; Weiss, et al., 2004; Cocherie 140 and Robert, 2007; Kylander et al., 2007b; Kylander, et al., 2009), respectively. Table 1 141 provides details of the measurement methods employed at each site. Note that cores 142 measured by Q-ICP-MS do not produce precise ${ }^{204} \mathrm{~Pb}$ data. The total ${ }^{206} \mathrm{~Pb} /{ }^{207} \mathrm{~Pb}$ ratio 143 variation observed in the pre-contamination portions of the selected records is, however, 144 greater than the analytical precision reported for each individual site (SM: 5.0\%, TM: 145 7.1\%, OM: 4.4\%, DM: 3.2\%, AM: 5.8\%, TrM: 7.7\%, EGR: 1.3\%, PVO: 11.0\%, PeW: $146 \quad 0.9 \%$, PbR2: 2.5\%, Sky1: 2.7\%, LyC: 3.9\%, PE: 1.5\%, CG: 0.5\%).

\section{$148 \quad 3.2$ Dating of pre-contamination peat}

149 In contrast to varved lake sediments and ice core records, the chronology of the peat 150 archives relies on indirect dating methods, such as ${ }^{14} \mathrm{C}$-dating or chronological markers 151 (pollen, tephras, etc.), instead of annual varve counting. Consequently, the dating

152 precision of the former is not as good. The uncertainty of the age-depth modeling used to 153 infer past atmospheric fluxes of $\mathrm{Pb}$ at an age interval of 6000-1000 B.C., which

154 represents the time-window of many of the sites included in this study, may reach \pm 1000

155 years. This uncertainty is generated by a typical uncertainty of about \pm 500 years for the

$156{ }^{14} \mathrm{C}$ calibration curve (Stuiver and Reimer, 1993) and an additional uncertainty of $<500$

157 years relating to the within bulk-sample variation in ${ }^{14} \mathrm{C}$-age (Nilsson et al., 2001). The 158 precision of the dating can be improved by dating each sample several times, but this is 159 rarely done and instead non-linear age-depth functions derived through fitting of several 
160 dates are used to constrain the age of the peat. In this review, we therefore do not attempt

161 to separate between events if the time difference is $<1000$ years.

\section{4. Isotopic composition of Pb Aerosol in Pre-contamination Peat}

\section{$164 \quad$ 4.1 Spatial and Temporal Variability}

165 The pollution history at most of the sites included here has been discussed in the original

166 papers, and in some cases synthesized as in Renberg et al. (2001) and Cloy et al. (2008).

167 We direct readers interested in $\mathrm{Pb}$ pollution history to these papers. The time span of the

168 pre-contamination peats discussed here is between 6000 and 1500 B.C. in Europe, from 169 the early $16^{\text {th }}$ century to the mid $17^{\text {th }}$ century A.D. in North America, 20 kyr B.P. and

1701900 A.D. in South America and 52 kyr B.P. in Australia.

171 Modern $\mathrm{Pb}$ containing aerosols are mainly anthropogenic in origin. This is seen in 172 the peat record where ${ }^{206} \mathrm{~Pb} /{ }^{207} \mathrm{~Pb}$ isotope ratios in Europe, for example, converge at

173 values around 1.14-1.18 in the surface peat (Figure 2), which is a range similar to that 174 reported for anthropogenic aerosols (Bollhöfer and Rosman, 2002) and evidences the use 175 of leaded petrol. In contrast to the modern, pollution-dominated atmosphere, the pre176 contamination atmosphere has an average ${ }^{206} \mathrm{~Pb} /{ }^{207} \mathrm{~Pb}$ ratio of $1.21 \pm 0.05(2 \sigma, \mathrm{n}=300)$ as

177 calculated by pooling all pre-contamination peat analyses (Table 2). This average

$178{ }^{206} \mathrm{~Pb} /{ }^{207} \mathrm{~Pb}$ ratio is the same as that from the pooled ice core estimate of $1.21 \pm 0.05(2 \sigma$, $179 \mathrm{n}=75)$ and is close to the estimated Holocene ${ }^{206} \mathrm{~Pb} /{ }^{207} \mathrm{~Pb}$ background ratio of $\sim 1.20$ from 180 Greenland ice from 150 kyr to 7 kyr (Rosman, et al., 1997; Burton et al., 2007) and 1.21 181 from the 220,000 year Antarctic ice core record (Vallelonga, et al., 2005), but diverges 
182 from the values of $\sim 1.23$ recorded in the Canadian Arctic (Zheng, et al., 2007) and 1.15

183 and 1.16 from Sajama Mountain in Bolivia (Rosman et al., 2003)(Figure 1).

184 Although the data are sparse, no strong geographic trend in average natural

$185{ }^{206} \mathrm{~Pb} /{ }^{207} \mathrm{~Pb}$ ratios in the pre-contamination peat is apparent (Figure 1). On the three-

186 isotope plots in Figures 3 and 4 many sites plot into a narrow, well-defined range and

187 some degree of regional agreement in behavior does seem to exist. The Swedish and

188 Spanish sites show a wider scatter than the Central European/Canadian and Southern

189 Hemisphere fields. The scatter in the Swedish and Spanish fields could reflect the fact

190 that these sites are surrounded by more radiogenic soils, generating more diverse ratios

191 when local soil dust mixes with non-local sources having lower ${ }^{206} \mathrm{~Pb} /{ }^{207} \mathrm{~Pb}$ signatures

192 (Table 2). The majority of Central European/Canadian and Southern Hemisphere sites sit

193 in areas dominated by sedimentary rocks which might explain the tightness of these fields

194 where the dusts deposited on the peat bogs from local sources are relatively well mixed

195 and/or depleted in U and Th containing minerals. While the GRIP records plot into a tight

196 field that overlaps with Central European/Canadian and Southern Hemisphere sites in

$197{ }^{206} \mathrm{~Pb} /{ }^{207} \mathrm{~Pb}$ vs. ${ }^{208} \mathrm{~Pb} /{ }^{206} \mathrm{~Pb}$ space (Figure 3), GRIP samples shows somewhat more scatter,

198 but still less than that observed in the Sajama Mountain and Dome C records, in $199{ }^{206} \mathrm{~Pb} /{ }^{204} \mathrm{~Pb}$ vs. ${ }^{207} \mathrm{~Pb} /{ }^{204} \mathrm{~Pb}$ and ${ }^{206} \mathrm{~Pb} /{ }^{204} \mathrm{~Pb}$ vs. ${ }^{208} \mathrm{~Pb} /{ }^{204} \mathrm{~Pb}$ space (Figure 3 ).

200 The fact that many of the polar ice and peat core records have an average 201 background ${ }^{206} \mathrm{~Pb} /{ }^{207} \mathrm{~Pb}$ ratio of $\sim 1.20$ could be interpreted as evidence for common 202 hemispheric $\mathrm{Pb}$ sources and/or effective homogenization of $\mathrm{Pb}$ signatures in the 203 atmosphere. The temporal trends in ${ }^{206} \mathrm{~Pb} /{ }^{207} \mathrm{~Pb}$ ratios in the pre-contamination peat 204 however, show few similarities. This is exemplified in Figure 2, which plots together all 
205 European records and shows significant variation in ${ }^{206} \mathrm{~Pb} /{ }^{207} \mathrm{~Pb}$ ratios, and hence source, 206 across the continent. In fact, the only indication of possible synchronicity in the records at 207 a long-distance or continental-scale occurs around 4000-3000 B.C. when ${ }^{206} \mathrm{~Pb} /{ }^{207} \mathrm{~Pb}$ 208 ratios decrease to values between 1.16 and 1.18 in Sweden, France and Spain (Figure 2a). 209 This event is weakly, if at all, expressed in Switzerland, although this could be a function 210 of the sampling resolution (Figure $2 \mathrm{~b}$ ). Given the large amount of samples involved, this 211 apparent decrease in ${ }^{206} \mathrm{~Pb} /{ }^{207} \mathrm{~Pb}$ ratios is unlikely to stem from analytical errors but 212 rather, as discussed later, from a common $\mathrm{Pb}$ aerosol event/period in Europe. It is unclear

213 if this event occurred in Greenland due to the poor sample integrity of the ice covering 214 the period from 5295 to 962 B.C. (Rosman et al., 1997).

215 The limited temporal synchronicity and different $\mathrm{Pb}$ isotopic composition of the 216 pre-contamination peat sections suggests that peat bogs capture aerosol $\mathrm{Pb}$ mainly from 217 local and regional sources. The importance of local soil dust is further indicated by higher $218{ }^{206} \mathrm{~Pb} /{ }^{207} \mathrm{~Pb}$ ratios in peat bogs surrounded by soils having high ${ }^{206} \mathrm{~Pb} /{ }^{207} \mathrm{~Pb}$ ratios as in 219 Sweden and Spain (Brännvall et al., 1999; Klaminder et al., 2003; Kylander et al., 2005).

220 In general, these regions also show the widest variability in ${ }^{206} \mathrm{~Pb} /{ }^{207} \mathrm{~Pb}$ ratios of $3-8 \%$ 221 (average across six sites is 5.5\%) and 11\% (6\% if excluding the two large excursions), 222 respectively. This wide range is indicative of periodic mixing of local sources with more 223 distant regional sources which generally have lower ${ }^{206} \mathrm{~Pb} /{ }^{207} \mathrm{~Pb}$ ratios (Table 2). Peat 224 records appear to capture regional atmospheric $\mathrm{Pb}$ cycles as indicated by similar $225{ }^{206} \mathrm{~Pb} /{ }^{207} \mathrm{~Pb}$ ratio trends in both the pre- and post-contamination peat (i.e., more than and 226 less than 3500 years ago, respectively) from southern Sweden (n=6) (Figure 2). Evidence 227 for the importance of local and regional contributions to atmospheric records was also 
228 found by Thompson et al. (1998) in their 22,000 year ice core record from Sajama

229 Mountain in Bolivia. In this case however, soil and crustal contributions were gauged

230 through the measurement of insoluble particulates (dust) rather than $\mathrm{Pb}$ isotopes.

231 We note that decreasing ${ }^{206} \mathrm{~Pb} /{ }^{207} \mathrm{~Pb}$ ratios in the Swedish peat bogs appear in $\sim 1000$

232 years cycles, i.e., 4200 B.C., 3100 B.C., 1900 B.C. and 1000 B.C. Bond cycles operate

233 on 1500-year-long climatic cycles in the North Atlantic and are known to have occurred

234 during the Holocene (Bond et al., 1997). Considering that periods with decreasing

$235{ }^{206} \mathrm{~Pb} /{ }^{207} \mathrm{~Pb}$ ratios occur in a partly cyclical manner it seems plausible that there is a link

236 between the temporal changes in the isotopic composition of the peat and climate change

237 in the North Atlantic, possibly through greater dune building/soil erosion during cold 238 periods.

239 Australia and North America are only represented by a single peat core each, while

240 South America is represented by three cores, making it difficult to interpret these records

241 in the context of regional atmospheric fallout. The pre-contamination period covered by

242 each of these records is variable as well, dating between 19,000 yr B.P. and 1900 A.D. at

243 South American sites, from the early $16^{\text {th }}$ century to the mid $17^{\text {th }}$ century A.D. in North

244 America and from $52 \mathrm{kyr}$ B.P. in Australia. Given the fact that several of these records

245 are much longer than those from Europe, the isotopic variability of the pre-contamination

246 sections at these sites is surprisingly low with $3 \%, 1 \%$ and $4 \%$ variability observed in

247 South America, North America and Australia, respectively. (The low variability observed

248 at the North American site is surely a product of the short temporal span of this core).

249 Many of these records also comfortably over-lap in time with the post-contamination 
250 period in Europe, but no evidence of the large scale $\mathrm{Pb}$ activities occurring on this

251 continent exist; rather, each record seems to reflect its own local/regional history.

252 The records from GRIP, Antarctica and Australia cover one or more glacial periods,

253 where significant changes in atmospheric aerosol loading occurred (Petit et al., 1990;

254 Steffensen, 1997; Delmonte, et al., 2004). The relatively limited variation in the

$255{ }^{206} \mathrm{~Pb} /{ }^{207} \mathrm{~Pb}$ ratio of the Australian peat (4\%) and Antarctic (5\%) ice, despite the fact that

256 changes in aerosol source undoubtedly occurred during these large climatic shifts,

257 suggest that the captured aerosols are derived from a few and/or isotopically homogenous

258 sources. In the case of the Australian record local and regional contributions are easy to

259 envisage while in Antarctica long range sources are likely to dominate due to the paucity

260 of local and regional sources. The record from Greenland shows greater variability (7\%)

261 in ${ }^{206} \mathrm{~Pb} /{ }^{207} \mathrm{~Pb}$ ratios between $150 \mathrm{kyr}$ and $7 \mathrm{kyr}$ which could reflect the fact that there are

262 more potential sources (i.e., land masses) in the Northern Hemisphere compared to the

263 Southern Hemisphere.

\section{$265 \quad 4.2$ Possible Natural Sources}

266 Natural sources of $\mathrm{Pb}$ in aerosols include mineral dusts, volcanoes, sea salt spray, forest

267 fires and biogenic particulates, where the latter three redistribute $\mathrm{Pb}$ ultimately derived 268 from the former (Nriagu, 1989; Freydier et al., 1999). The importance of volcanic and

269 soil dust-derived $\mathrm{Pb}$ in the atmosphere has been debated (e.g., Hong et al., 1996; Hinkley

270 et al., 1999; Hong et al., 2003; Hinkley, 2007). Lead isotopes have been an important tool

271 in separating volcanic and soil-derived $\mathrm{Pb}$ in polar ice-core records (Van de Velde et al.,

272 2005). Soil-derived $\mathrm{Pb}$ generally has a ${ }^{206} \mathrm{~Pb} /{ }^{207} \mathrm{~Pb}$ ratio $\geq 1.19$. For example, the major 
273 soil dust emitting areas on a global scale, including the Sahara-Sahel area (Sun, 1980;

274 Abouchami and Zabel, 2003), Saharan Holocene loess (Grousset et al., 1994), Gobi

275 desert (Biscaye, et al., 1997) and European loess soils (Klaminder, et al., 2003;

276 Sterckeman et al., 2006), have ${ }^{206} \mathrm{~Pb} /{ }^{207} \mathrm{~Pb}$ ratios varying between 1.19 and 1.25 . Volcanic

$277 \mathrm{~Pb}$ on the other hand, may show a larger variation depending on the proportional mixing

278 between mantle sources and the crust.

279 Lead three-isotope plots of the pre-contamination peat sections and possible

280 natural sources are shown in Figures 5 and 6 . These natural sources are represented by

281 sediments from the North Atlantic (Farmer et al., 2003) and North (Jones et al., 2000;

282 Pettke et al., 2000) and Southwest Pacific (Stancin et al., 2008), which mirror mineral

283 dust from the continents; sediments from rivers worldwide, which represents the upper

284 continental crust (UCC)(Millot et al., 2004); loess from China (Biscaye, et al., 1997;

285 Jones, et al., 2000), Mongolia, North America (Biscaye, et al., 1997), New Zealand

286 (Stancin, et al., 2008), and France (Sterckeman, et al., 2006), which typifies mineral dust

287 from the continents; volcanic rocks from Italy (Ayuso et al., 1998; De Astis et al., 2000;

288 Viccaro and Cristofolini, 2008), Spain (Cebriá et al., 2000), France (Downes and Dupuy,

289 1987; Wittig et al., 2007), Iceland (Sun and Jahn, 1975; Sun et al., 1975; Thirlwall et al.,

290 2004), Greece (Pe-Piper, 1998), Faroe Islands (Holm et al., 2001) and Canary Islands

291 (Sun, 1980; Praegel and Holm, 2006) to constrain volcanic sources; and mid-ocean ridge

292 basalts (MORB) are included for reference (Sun, 1980). Note that there is no documented

293 volcanic activity on the Faroe Islands during the Holocene and we include these data only

294 as a proxy for sub-marine volcanoes that can be expected to develop along the Icelandic-

295 Faroe fault line. 
297 Central European/Canadian, Southern Hemisphere and GRIP fields. These source fields

298 overlap with previous estimates of the UCC in ${ }^{206} \mathrm{~Pb} /{ }^{207} \mathrm{~Pb}$ vs. ${ }^{208} \mathrm{~Pb} /{ }^{206} \mathrm{~Pb}$ space (Figure

299 5), but less so in ${ }^{206} \mathrm{~Pb} /{ }^{204} \mathrm{~Pb}$ vs. ${ }^{207} \mathrm{~Pb} /{ }^{204} \mathrm{~Pb}$ and ${ }^{208} \mathrm{~Pb} /{ }^{204} \mathrm{~Pb}$ space (Figure 6). The scatter

300 in the Swedish and Spanish sites and position of the various volcanic fields suggests that

301 at these sites volcanic additions could be more important. It is, however, difficult to

302 separate the effects of the radiogenic backgrounds at these sites from volcanic

303 contributions vis-à-vis defining the importance of mineral dusts.

304 The UCC and its estimated composition are commonly used as a reference in 305 mixing equations when aiming to characterize $\mathrm{Pb}$ derived from natural sources. Kramers

306 and Tolstikhim (1997) modelled ${ }^{206} \mathrm{~Pb} /{ }^{204} \mathrm{~Pb}$ values of $18.68-19.11$ for the upper

307 continental crust. Values of 19.32 (Asmerom and Jacobsen, 1993) and 19.22 (Hemming

308 and McLennan, 2001) have been estimated based on the measurement of suspended

309 matter in rivers and deep sea turbidites, respectively (Table 2). Estimates of the UCC

310 made using sediments from rivers worldwide have predicted ${ }^{206} \mathrm{~Pb} /{ }^{204} \mathrm{~Pb}$ values of 19.07

311 and 18.93, using sediment flux and surface area balancing methods, respectively (Millot,

312 et al., 2004). The global average isotopic composition of ${ }^{204} \mathrm{~Pb}$-normalized ratios in the

313 peat cores $\left({ }^{206} \mathrm{~Pb} /{ }^{204} \mathrm{~Pb}=18.90,{ }^{207} \mathrm{~Pb} /{ }^{204} \mathrm{~Pb}=15.66,{ }^{208} \mathrm{~Pb} /{ }^{204} \mathrm{~Pb}=38.74\right)$, as well as the

314 available ice core data, falls below many previous approximations of the UCC, with the

315 main exception being the modelled data of Kramers and Tolstikhim (1997). This is also

316 apparent on the three-isotope plots in Figures 3 and 4, where many of the pre-

317 contamination data points do not fall into the published UCC range and vary widely

318 around it. In fact, it is Lynch's Crater in Australia, the only site located in a volcanic 
319 setting, which overall falls closest to these approximations (Table 2). As argued

320 previously, the pre-contamination peat is representative of a mixture between local and

321 regional sources. In theory the UCC should be representative of the unweathered upper

322 crust. Contributions from crustal sources, however, are likely in the form of eroded soils.

323 Alteration of $\mathrm{Pb}$ isotope signatures is known to occur during some soil and bedrock

324 weathering processes (Harlavan et al., 1998; Harlavan and Erel, 2002; Kylander et al.,

325 2008). As such we may not expect the isotopic composition of these two fields (pre-

326 contamination peat/ice and UCC) to be similar, particularly when contributions from,

327 e.g., volcanic sources to the pre-contamination peat may have occurred. The use of the

328 UCC as a natural end-member in mixing equations should therefore be carefully assessed

329 on a site-by-site basis and thoroughly consider the surrounding geology and all possible

$330 \mathrm{~Pb}$ sources.

331 Major natural atmospheric $\mathrm{Pb}$ sources generally have ${ }^{206} \mathrm{~Pb} /{ }^{207} \mathrm{~Pb}$ ratios $\geq 1.19$ and it 332 is often assumed that an input of $\mathrm{Pb}$ with a ${ }^{206} \mathrm{~Pb} /{ }^{207} \mathrm{~Pb}$ ratio less than 1.19 is 333 anthropogenic in source (Klaminder, et al., 2003). However, in our data ${ }^{206} \mathrm{~Pb} /{ }^{207} \mathrm{~Pb}$ ratios

334 below 1.19 are also occasionally found in the pre-contamination peat record. For 335 example, ${ }^{206} \mathrm{~Pb} /{ }^{207} \mathrm{~Pb}$ and ${ }^{208} \mathrm{~Pb} /{ }^{206} \mathrm{~Pb}$ ratios around 1.16 and 2.1 , respectively, are present

336 in both the Spanish and Swedish peat deposited between 4000-3000 B.C. Klaminder et al.

337 (2003) and Kylander et al. (2005) hypothesized that the possible origin of this $\mathrm{Pb}$ was

338 anthropogenic given that small-scale copper mines were operating at this time in Europe

339 (Nriagu, 1983). New isotopic data from other pre-contamination peat sections, potential

340 natural volcanic sources and polar ice-record have been published since, which suggest

341 that natural sources are more likely. First, ${ }^{206} \mathrm{~Pb} /{ }^{207} \mathrm{~Pb}$ ratios as low as 1.17 are found in 
342 peat layers deposited several thousand years prior to modern contamination in Australia

343 and Southern Chile (Figures 3 and 4), supporting the existence of natural sources with

344 low ${ }^{206} \mathrm{~Pb} /{ }^{207} \mathrm{~Pb}$ ratios. This finding is supported by ice-core data showing that $\mathrm{Pb}$ with a

$345{ }^{206} \mathrm{~Pb} /{ }^{207} \mathrm{~Pb}$ ratio around 1.16 has accumulated in more than 7000 year-old arctic ice from

346 Canada (Zheng, et al., 2007) and 19,000 year old ice in Bolivia (Rosman et al., 2003) and

$347 \mathrm{~Pb}$ with a ${ }^{206} \mathrm{~Pb} /{ }^{207} \mathrm{~Pb}$ ratio around 1.18 has been recorded in more than 7000 year-old

348 arctic ice from Greenland (Burton et al., 2007). With these new data in mind it is clear

349 that there are important natural atmospheric $\mathrm{Pb}$ sources having ${ }^{206} \mathrm{~Pb} /{ }^{207} \mathrm{~Pb}$ ratios as low

350 as 1.16-1.18. Furthermore, it seems that these sources were important globally in the pre-

351 contamination environment given that $\mathrm{Pb}$ with a ${ }^{206} \mathrm{~Pb} /{ }^{207} \mathrm{~Pb}$ ratio below 1.18 occurs both

352 in ice from the Arctic and Bolivia and in peat bogs in Europe, Australia and southern 353 Chile.

354 The isotopic excursions marking the European $\mathrm{Pb}$ event are highlighted in Figure 5 355 (dashed circle) and indeed plot into the fields for the Faroe Island and Icelandic 356 volcanoes, rather than loess soils, in ${ }^{206} \mathrm{~Pb} /{ }^{207} \mathrm{~Pb}$ vs. ${ }^{208} \mathrm{~Pb} /{ }^{206} \mathrm{~Pb}$ space (only $\mathrm{PVO}$ is 357 represented in the ${ }^{206} \mathrm{~Pb} /{ }^{204} \mathrm{~Pb}$ vs. ${ }^{207} \mathrm{~Pb} /{ }^{204} \mathrm{~Pb}$ and ${ }^{208} \mathrm{~Pb} /{ }^{204} \mathrm{~Pb}$ plots). The provenance of $\mathrm{Pb}$ 358 having ${ }^{206} \mathrm{~Pb} /{ }^{207} \mathrm{~Pb}$ ratios as low as $1.16-1.18$ in Europe is thus likely to be volcanic.

359 Tephras (volcanic ash) are found in peat layers deposited throughout the Holocene in 360 western and central Europe having mainly an Icelandic origin (Van Den Bogaard and 361 Schmincke, 2002; Blockley et al., 2007). Isotopic measurements of volcanic rocks from 362 Iceland and the Faroe Islands also illustrate that North Atlantic volcanoes can emit $\mathrm{Pb}$ 363 with ${ }^{206} \mathrm{~Pb} /{ }^{207} \mathrm{~Pb}$ ratios as low as 1.16 (Thirlwall, et al., 2004). We note that this 364 volcanically derived $\mathrm{Pb}$ may, however, not necessarily be related to explosive terrestrial 
365 volcanic eruptions. Rather, as suggested by Hinkley (2007), that the quiescent degassing

366 of volcanoes could be main source of $\mathrm{Pb}$ containing aerosols. The period between 5000

367 and 1000 B.C. is known to be a period of relatively low volcanic activity on Iceland

368 (Larsen and Eiríksson, 2008). As such, it is plausible that the archived $\mathrm{Pb}$ with low

$369{ }^{206} \mathrm{~Pb} /{ }^{207} \mathrm{~Pb}$ ratios is derived from passive degassing and/or sub-marine volcanic activity.

370 That the volcanically derived $\mathrm{Pb}$ is not necessarily related to explosive volcanic eruptions

371 is supported by the existence of periods with low ${ }^{206} \mathrm{~Pb} /{ }^{207} \mathrm{~Pb}$ ratios and increasing $\mathrm{Pb}$

372 concentrations that do not co-occur with the tephra (volcanic ash) layers $(n=4)$ in the

373 Patagonian profile (not shown). Measurements on volcanic rocks from the Central

374 Volcanic Zone of the Andes have indeed found ${ }^{206} \mathrm{~Pb} /{ }^{207} \mathrm{~Pb}$ ratios as low as 1.15 (Bourdon

375 et al., 2000). Using the dataset compiled here however it is not possible to do more than

376 speculate on the importance of quiescent degassing or explosive volcanic eruptions.

377 Pre-contamination peat sections from South America, Australia and Antarctica have 378 overlapping fields in ${ }^{206} \mathrm{~Pb} /{ }^{207} \mathrm{~Pb}$ vs. ${ }^{208} \mathrm{~Pb} /{ }^{206} \mathrm{~Pb}$ space (Figure 3), and to a lesser extent $379{ }^{206} \mathrm{~Pb} /{ }^{204} \mathrm{~Pb}$ vs. ${ }^{207} \mathrm{~Pb} /{ }^{204} \mathrm{~Pb}$ and ${ }^{208} \mathrm{~Pb} /{ }^{204} \mathrm{~Pb}$ space (Figure 4). The overlap in Australian and

380 Antarctic fields may be significant in that the source(s) of $\mathrm{Pb}$ containing aerosols to the

381 South Pole has not been unequivocally identified. To date most focus has been placed on

382 South American sources (e.g., Delmonte et al., 2004; Vallelonga, et al., 2005), although

383 there is a general lack of data with which to work with (Kohfeld and Harrison, 2001). The

384 Australian record presents $\mathrm{Pb}$ isotope values reflecting contributions from sources across

385 the eastern part of the country (Kylander, et al., 2007a) and given this overlap in fields,

386 suggests that Australian aerosol sources might be worth considering as contributors to

387 Antarctic sites. In support of this hypothesis, Revel-Rolland et al. (2006) have shown, 
using $\mathrm{Sr}$ and $\mathrm{Nd}$ isotope data, that soil dust contributions to eastern Antarctica from

389 Australia were important during interglacial, but not glacial, periods.

\section{$391 \quad$ 5. Conclusions}

392 - The peat archive appears to consist mainly of $\mathrm{Pb}$ derived from atmospheric 393 transport from local $(<10 \mathrm{~km})$ and regional $(10-500 \mathrm{~km})$ sources, as indicated by 394 the limited co-variance in temporal trends in the ${ }^{206} \mathrm{~Pb} /{ }^{207} \mathrm{~Pb}$ ratio at a long395 distance/continental scale (Europe) and regional differences in the isotopic composition of the peat sections. Consequently, $\mathrm{Pb}$ isotope analysis of peat cores is unlikely to reveal useful information about hemispheric-scale circulation patterns and source area conditions.

- The region specific isotopic composition of the pre-contamination peat suggests that $\mathrm{Pb}$ isotope analysis of peat cores, in combination with other climatic proxies, could be useful when assessing regional aerosol dynamics in the past and their response to climatic events. For example, in near coastal regions, such as the studied sites in southwest Sweden where the variation in the $\mathrm{Pb}$ isotopic composition of the aerosols appears to be related to oceanic sources, such analyses can offer a possibility to reconstruct regional climatic changes related to oceanic and atmospheric circulation patterns.

- Natural sources having a ${ }^{206} \mathrm{~Pb} /{ }^{207} \mathrm{~Pb}$ ratio as low as 1.16 were active world-wide in the pre-contamination environment. Mixing calculations where natural sources are assigned $\mathrm{a}{ }^{206} \mathrm{~Pb} /{ }^{207} \mathrm{~Pb}$ ratio of $\sim 1.20$ or above, may therefore lead to an 
aerosols derived from volcanic sources appear to be the most likely source of this $\mathrm{Pb}$ having ${ }^{206} \mathrm{~Pb} /{ }^{207} \mathrm{~Pb}$ ratios much lower than that typically considered representative for atmospheric $\mathrm{Pb}$ in the pristine environment.

- This compilation of pre-contamination records of atmospheric $\mathrm{Pb}$ preserved in peat bogs world-wide suggest an atmospheric $\mathrm{Pb}$ aerosol composition that departs from that of the polar-ice records by showing higher temporal variations in the ${ }^{206} \mathrm{~Pb} /{ }^{207} \mathrm{~Pb}$ ratios and a different multi-isotope composition. Hence, inferring regional aerosol sources at lower altitudes and lower latitudes from polar ice-core records, which are more likely to represent an integrated hemispheric signal,

\section{Acknowledgements}

423 The authors would like to thank Bernd Kober, Jan Kramers and Antonio Martinez-

424 Cortizas as well as their co-workers and colleagues for their fruitful discussions over the 425 years. Two anonymous reviewers are also thanked for their contribution to this work. 426 This project was made possible by financial support from NERC, Imperial College 427 London, the Natural History Museum London, Universities UK ORS Scholarship and 428 Vetenskapsrådets Postdoctoral Fellowship to MEK. 


\section{References}

432

433

434

435

436

437

438

439

440

441

442

443

444

445

446

447

448

449

450

451

452

453

454

455

456

457

458

459

460

461

462

463

464

465

466

467

468

469

470

471

472

473

474

475

476

477

478

479

480

481

482

483

484

Abouchami, W., Zabel, M., 2003. Climate forcing of the $\mathrm{Pb}$ isotope record of terrigenous input into the Equatorial Atlantic. Earth Planet. Sci. Lett. 213, 221-234.

Allegre, C.J., Manhes, G., Gopel, C., 1995. The Age of the Earth. Geochim. Cosmochim. Acta 59, 14451456.

Allegre, C.J., Manhes, G., Gopel, C., 2008. The major differentiation of the Earth at similar to $4.45 \mathrm{Ga}$. Earth Planet. Sci. Lett. 267, 386-398.

Asmerom, Y., Jacobsen, S.B., 1993. The Pb Isotopic Evolution of the Earth - Inferences from River Water Suspended Loads. Earth Planet. Sci. Lett. 115, 245-256.

Aung, N.N., Uryu, T., Yoshinaga, J., 2004. Lead Isotopic Compositions of Environmental Certified Reference Materials for an Inter-Laboratory Comparison of Lead Isotope Analysis. Anal. Sci. 20, 195-198.

Ayuso, R.A., De Vivo, B., Rolandi, G., Seal, R.R., Paone, A., 1998. Geochemical and isotopic (Nd-Pb-SrO) variations bearing on the genesis of volcanic rocks from Vesuvius, Italy. J. Volcanol. Geotherm. Res. 82, 53-78.

Becker, J.S., 2002. State-of-the-art and progress in precise and accurate isotope ratio measurements by ICPMS and LA-ICP-MS. J. Anal. At. Spectrom. 17, 1172-1185.

Begley, I.S., Sharp, B.L., 1997. Characterisation and correction of instrumental bias in inductively coupled plasma quadrupole mass spectrometry for accurate measurement of lead isotope ratios. J. Anal. At. Spectrom. 12, 395-402.

Belshaw, N.S., Freedman, P.A., O'Nions, R.K., Frank, M., Guo, Y., 1998. A new variable dispersion double-focusing plasma spectrometer with performance illustrated for $\mathrm{Pb}$ isotopes. Int. J. Mass Spec. 181, 51-58.

Biscaye, P.E., Grousset, F.E., Revel, M., Gaast, V.S., Zielinski, G.A., Vaars, A., Kukla, G., 1997. Asian provenance of glacial dust (stage 2) in the Greenland Ice Sheet Project 2 ice core Summit Greenland. J. Geophys. Res. 102, 26,765-726,781.

Blockley, S.P.E., Lane, C.S., Lotter, A.F., Pollard, A.M., 2007. Evidence for the presence of the Vedde Ash in Central Europe. Quat. Sci. Rev. 26, 3030-3036.

Bollhofer, A., Rosman, K.J.R., 2002. The temporal stability in lead isotopic signatures at selected sites in the Southern and Northern Hemispheres. Geochim. Cosmochim. Acta 66, 1375-1386.

Bond, G., Showers, W., Cheseby, M., Lotti, R., Almasi, P., deMenocal, P., Priore, P., Cullen, H., Hajdas, I., Bonani, G., 1997. A pervasive millennial-scale cycle in North Atlantic Holocene and glacial climates. Science 278, 1257-1266.

Bourdon, B., Wörner, G., Zondler, A., 2000. U-series evidence for crustal involvement and magma residence times in the petrogenesis of Parinacota volcano, Chile. Contrib. Mineral. Petrol. 139, 458-469.

Brännvall, M.-L., Bindler, R., Renberg, I., Emteryd, O., Bartnicki, J., Billström, K., 1999. The Medieval metal industry was the cradle of modern large-scale atmospheric lead pollution in northern Europe. Environ. Sci. Technol. 33, 4391-4395.

Brännvall, M.L., Bindler, R., Emteryd, O., Nilsson, M., Renberg, I., 1997. Stable isotope and concentration records of atmospheric lead pollution in peat and lake sediments in Sweden. Water Air Soil Poll. $100,243-252$.

Burton, G.R., Rosman, K.J.R., Candelone, J.P., Burn, L.J., Boutron, C.F., Hong, S.M., 2007. The impact of climatic conditions on $\mathrm{Pb}$ and $\mathrm{Sr}$ isotopic ratios found in Greenland ice, 7-150 ky BP. Earth Planet. Sci. Lett. 259, 557-566.

Carignan, J., Simonetti, A., Gariepy, C., 2002. Dispersal of atmospheric lead in northeastern North America as recorded by epiphytic lichens. Atmos. Environ. 36, 3759-3766.

Cebriá, J.M., López-Ruiz, J., Doblas, M., Oyarzun, R., Hertogen, J., Benito, R., 2000. Geochemistry of the Quaternary alkali basalts of Garrotxa (NE Volcanic Province, Spain): a case of double enrichment of the mantle lithosphere. J. Volcanol. Geotherm. Res. 102, 217-235.

Cloy, J.M., Farmer, J.G., Graham, M.C., MacKenzie, A.B., Cook, G.T., 2008. Historical records of atmospheric $\mathrm{Pb}$ deposition in four Scottish ombrotrophic bogs: An isotopic comparison with other records from western Europe and Greenland. Glob. Biogeochem. Cy. 22, GB2016. 
Cocherie, A., Robert, M., 2007. Direct measurement of lead isotope ratios in low concentration environmental samples by MC-ICP-MS and multi-ion counting. Chem. Geol. 243, 90-104.

De Astis, G., Peccerillo, A., Kempton, P.D., La Volpe, L., Wu, T.W., 2000. Transition from calc-alkaline to potassium-rich magmatism in subduction environments: geochemical and $\mathrm{Sr}, \mathrm{Nd}, \mathrm{Pb}$ isotopic constraints from the island of Vulcano (Aeolian arc). Contrib. Mineral. Petrol. 139, 684-703.

Delmonte, B., Basile-Doelsch, I., Petit, J.R., Maggi, V., Revel-Rolland, M., Michard, A., Jagoutz, E., Grousset, F., 2004. Comparing the Epica and Vostok dust records during the last 220,000 years: stratigraphical correlation and provenance in glacial periods. Earth-Sci. Rev. 66, 63-87.

Dickin, A., 2009. Radiogenic Isotope Geology, 2nd. Cambridge University Press, Cambridge.

Downes, H., Dupuy, C., 1987. Textural, Isotopic and REE Variations in Spinel Peridotite Xenoliths, Massif-Central, France. Earth Planet. Sci. Lett. 82, 121-135.

Farmer, G.L., Barber, D., Andrews, J., 2003. Provenance of Late Quaternary ice-proximal sediments in the North Atlantic: Nd, Sr and Pb isotopic evidence. Earth Planet. Sci. Lett. 209, 227-243.

Freydier, R., Dupre, B., Delmas, R., 1999. Lead in rainwaters from intertropical Africa: Natural or anthropogenic origin? J. Geophys. Res. 104, 16001-16008.

Grousset, F.E., Quetel, C.R., Thomas, B., Buatmenard, P., Donard, O.F.X., Bucher, A., 1994. Transient Pb Isotopic Signatures in the Western-European Atmosphere. Environ. Sci. Technol. 28, 1605-1608.

Harlavan, Y., Erel, Y., 2002. The release of $\mathrm{Pb}$ and REE from granitoids by the dissolution of accessory phases. Geochim. Cosmochim. Acta 66, 837-848.

Harlavan, Y., Erel, Y., Blum, J.D., 1998. Systematic Changes in Lead Isotopic Composition with Soil Age in Glacial Granitic Terrains. Geochim. Cosmochim. Acta 62, 33-46.

Hemming, S.R., McLennan, S.M., 2001. Pb isotope compositions of modern deep sea turbidites. Earth Planet. Sci. Lett. 184, 489-503.

Hinkley, T., 2007. Lead (Pb) in old Antarctic ice: Some from dust, some from other sources. Geophys. Res. Lett. 34, L17710.

Hinkley, T.K., Lamothe, P.J., Wilson, S.A., Finnegan, D.L., Gerlach, T.M., 1999. Metal emissions from Kilauea, and a suggested revision of the estimated worldwide metal output by quiescent degassing of volcanoes. Earth. Planet. Sci. Lett. 170, 315-325.

Hofmann, A., 1997. Mantle geochemistry: the message from oceanic volcanism. Nature 385, 219-229.

Holm, P.M., Hald N., Waagstein R., 2001. Geochemical and Pb-Sr-Nd isotopic evidence for separate hot depleted and Iceland plume mantle sources for the Paleogene basalts of the Faroe Islands. Chem. Geol. 178, 95-125.

Hong, S., Candelone, J.P., Turetta, C., Boutron, C.F., 1996. Changes in natural lead, copper, zinc, cadmium concentrations in central Greenland ice from 8250 to 149,100 years ago: their association with climatic changes and resultant variations of dominant source contributions. Earth Planet. Sci. Lett. 143, 233-244.

Hong, S.M., Kim, Y., Boutron, C.F., Ferrari, C.P., Petit, J.R., Barbante, C., Rosman, K., Lipenkov, V.Y., 2003. Climate-related variations in lead concentrations and sources in Vostok Antarctic ice from 65,000 to 240,000 years BP. Geophys. Res. Lett. 30, 2138.

Jones, C.E., Halliday, A.N., Rea, D.K., Owen, R.M., 2000. Eolian inputs of lead to the North Pacific. Geochim. Cosmochim. Acta 64, 1405-1416.

Klaminder, J., Renberg, I., Bindler, R., Emteryd, O., 2003. Isotopic trends and background fluxes of atmospheric lead in northern Europe: Analyses of three ombrotrophic bogs from south Sweden. Glob. Biogeochem. Cy. 17, 1019.

Kohfeld, K.E., Harrison, S.P., 2001. DIRTMAP: the geological record of dust. Earth-Sci. Rev. 54, 91-114.

Kramers, J.D., Tolstikhim, I.N., 1997. Two terrestrial lead isotope paradoxes, forward transport modelling, core formation and the history of the continental crust. Chem. Geol. 139, 75-110.

Kylander M.E., Martinez-Cortizas, A., Weiss, D.J., Rauch, S. (2008). Lead Penetration and Leaching in a Complex Temperate Soil Profile. Environ. Sci. Tech. 42, 3177 - 3184.

Kylander, M.E., Muller, J., Wust, R.A.J., Gallagher, K., Garcia-Sanchez, R., Coles, B.J., Weiss, D.J., 2007a. Rare earth element and $\mathrm{Pb}$ isotope variations in a $52 \mathrm{kyr}$ peat core from Lynch's Crater (NE Queensland, Australia): Proxy development and application to paleoclimate in the Southern Hemisphere. Geochim. Cosmochim. Acta 71, 942-960.

Kylander, M.E., Weiss, D.J., Cortizas, A.M., Spiro, B., Garcia-Sanchez, R., Coles, B.J., 2005. Refining the pre-industrial atmospheric $\mathrm{Pb}$ isotope evolution curve in Europe using an 8000 year old peat core from NW Spain. Earth Planet. Sci. Lett. 240, 467-485. 
Kylander, M.E., Weiss, D.J., Jeffries, T.E., Kober, B., Dolgopolova, A., Garcia-Sanchez, R., Coles, B.J., 2007b. A rapid and reliable method for Pb isotopic analysis of peat and lichens by laser ablationquadrupole-inductively coupled plasma-mass spectrometry for biomonitoring and sample screening. Anal. Chim. Acta 582, 116-124.

Kylander, M.E., Weiss, D.J., Kober, B., 2009. Two high resolution terrestrial records of atmospheric $\mathrm{Pb}$ deposition from New Brunswick, Canada, and Loch Laxford, Scotland. Sci. Total Environ. 407, 1644-1657.

Larsen, G., Eiríksson, J., 2008. Late Quaternary terrestrial tephrochronology of Iceland-frequency of explosive eruptions, type and volume of tephra deposits. J Quat. Sci. 23, 109-120-

Millot, R., Allegre, C.-J., Gaillardet, J., Roy, S., 2004. Lead isotopic systematics of major river sediments: a new estimate of the Pb isotopic composition of the Upper Continental Crust. Chem. Geol. 203, 75 90.

Monna, F., Galop, D., Carozza, L., Tual, M., Beyrie, A., Marembert, F., Chateau, C., Dominik, J., Grousset, F., 2004. Environmental impact of early Basque mining and smelting recorded in a high ash minerogenic peat deposit. Sci. Tot. Environ. 327, 197-214.

Nilsson, M., Klarqvist, M., Bohlin, E., Possnert, G., 2001. Variation in C-14 age of macrofossils and different fractions of minute peat samples dated by AMS. Holocene 11, 579-586.

Nowack, B., Obrecht, J.M., Schluep, M., Schulin, R., Hansmann, W., Koppel, V., 2001. Elevated lead and zinc contents in remote alpine soils of the Swiss National Park. J. Enviro. Qual. 30, 919-926.

Nriagu, J.O., 1983. Lead and lead poisoning in antiquity, Wiley-Interscience, NY, USA.

Nriagu, J.O., 1989. A Global Assessment of Natural Sources of Atmospheric Trace- Metals. Nature 338, 47-49.

Pe-Piper, G., 1998. The nature of Triassic extension-related magmatism in Greece: evidence from Nd and $\mathrm{Pb}$ isotope geochemistry. Geol. Mag. 135, 331-348.

Petit, J.R., Mounier, L., Jouzel, J., Korotkevich, Y.S., Kotlyakov, V.I., Lorius, C., 1990. Palaeoclimatological and Chronological Implications of the Vostok Core Dust Record. Nature 343, 56-58.

Pettke, T., Halliday, A.N., Hall, C.M., Rea, D.K., 2000. Dust production and deposition in Asia and the north Pacific Ocean over the past 12 Myr. Earth Planet. Sci. Lett. 178, 397-413.

Praegel, N.O., Holm, P.M., 2006. Lithospheric contributions to high-MgO basanites from the Cumbre Vieja Volcano, La Palma, Canary Islands and evidence for temporal variation in plume influence. J. Volcanol. Geotherm. Res. 149, 213-239.

Quetel, C.R., Thomas, B., Donard, O.F.X., Grousset, F.E., 1997. Factorial optimization of data acquisition factors for lead isotope ratio determination by inductively coupled plasma mass spectrometry. Spectroc. Acta Pt. B-Atom. Spectr. 52, 177-187.

Rehkamper, M., Halliday, A.N., 1998. Accuracy and long-term reproducibility of lead isotopic measurements by multiple-collector inductively coupled plasma mass spectrometry using an external method for correction of mass discrimination. Int. J. Mass Spec. 181, 123-133.

Renberg, I., Bindler, R., Brannvall, M.L., 2001. Using the historical atmospheric lead-deposition record as a chronological marker in sediment deposits in Europe. Holocene 11, 511-516.

Revel-Rolland, M., De Deckker, P., Delmonte, B., Hesse, P.P., Magee, J.W., Basile-Doelsch, I., Grousset, F., Bosch, D., 2006. Eastern Australia: A possible source of dust in East Antarctica interglacial ice. Earth Planet. Sci. Lett. 249, 1-13.

Rosman, K.J.R., Chisholm, W., Hong, S.M., Candelone, J.P., Boutron, C.F., 1997. Lead from Carthaginian and Roman Spanish mines isotopically identified in Greenland ice dated from 600 BC to $300 \mathrm{AD}$. Environ. Sci. Technol. 31, 3413-3416.

Rosman, K.J.R., Ly, C., Steinnes, E., 1998. Spatial and temporal variation in isotopic composition of atmospheric lead in Norwegian moss. Environ. Sci. Technol. 32, 2542-2546.

Semlali, R.M., Oort, F.v., Denaix, L., Loubet, M., 2001. Estimating distributions of endogenous and exogenous $\mathrm{Pb}$ in soils using $\mathrm{Pb}$ isotopic ratios. Environ. Sci. Technol. 35, 4180-4188.

Shirahata, H., Elias, R.W., Patterson, C.C., 1980. Chronological variations in concentrations and isotopic compositions of anthropogenic atmospheric lead in sediments of a remote subalpine pond. Geochim. Cosmochim. Acta 44, 149-162.

Shotyk, W., Weiss, D., Kramers, J.D., Frei, R., Cheburkin, A.K., Gloor, M., Reese, S., 2001. Geochemistry of the peat bog at Etang de la Gruere, Jura Mountains, Switzerland, and its record of atmospheric 
$\mathrm{Pb}$ and lithogenic trace metals ( $\mathrm{Sc}, \mathrm{Ti}, \mathrm{Y}, \mathrm{Zr}$, and $\mathrm{REE}$ ) since $12,370{ }^{14} \mathrm{C}$ yr BP. Geochim. Cosmochim. Acta 65, 2337-2360.

Simonetti, A., Gariepy, C., Banic, C.M., Tanabe, R., Wong, H.K., 2004. Pb isotopic investigation of aircraft-sampled emissions from the Horne smelter (Rouyn, Quebec): Implications for atmospheric pollution in northeastern North America. Geochim. Cosmochim. Acta 68, 3285-3294.

Spiro B., Weiss, D.J., Purvis, O.W., Mikhailova, I., Williamson, B., Udachin, V., 2004. Pb isotopes in lichen transplants - transient records of diverse sources around the Karabash smelter, Urals, Russia. Environ. Sci. Technol. 38, 6522-6528.

Stancin, A.M., Gleason, J.D., Hovan, S.A., Rea, D.K., Owen, R.M., Moore, T.C., Hall, C.M., Blum, J.D., 2008. Miocene to recent eolian dust record from the Southwest Pacific Ocean at 40 degrees S latitude. Palaeogeogr. Palaeoclimatol. Palaeoecol. 261, 218-233.

Steffensen, J.P., 1997. The size distribution of microparticles from selected segments of the Greenland Ice Core Project ice core representing different climatic periods. J. Geophys. Res. 102, 26755-26763.

Sterckeman, T., Douay, F., Baize, D., Fourrier, H., Proix, N., Schvartz, C., Carignan, J., 2006. Trace element distributions in soils developed in loess deposits from northern France. Eur. J. Soil Sci. 57, 392-410.

Stuiver, M., Reimer, P.J., 1993. Extended $\mathrm{C}^{14}$ data-base and revised Calib $3.0 \mathrm{C}^{14}$ age calibration program. Radiocarbon 335, 215-230.

Sun, S.-S., 1980. Lead isotopic study of young volcanic rocks from mid-ocean ridges, ocean islands and island arcs. Philos. T. Roy. Soc. A 297, 409-445.

Sun, S.S., Jahn, B., 1975. Lead and Strontium Isotopes in Postglacial Basalts from Iceland. Nature 255, 527-530.

Sun, S.S., Tatsumoto, M., Schilling, J.G., 1975. Mantle Plume Mixing Along Reykjanes Ridge Axis - Lead Isotopic Evidence. Science 190, 143-147.

Thirlwall, M.F., 2002. Multicollector ICP-MS analysis of $\mathrm{Pb}$ isotopes using a ${ }^{207} \mathrm{~Pb}-{ }^{204} \mathrm{~Pb}$ double spike demonstrates up to $400 \mathrm{ppm} / \mathrm{amu}$ systematic errors in Tl-normalization. Chem. Geol. 184, 255279.

Thirlwall, M.F., Gee, M.A.M., Taylor, R.N., Murton, B.J., 2004. Mantle components in Iceland and adjacent ridges investigated using double-spike $\mathrm{Pb}$ isotope ratios. Geochim. Cosmochim. Acta 68, 361-386.

Thompson, L.G., Davis, M.E., Mosley-Thompson, E., Sowers, T.A., Henderson, K.A., Zagorodnov, V.S., Lin, P.N., Mikhalenko, V.N., Campen, R.K., Bolzan, J.F., Cole-Dai, J., Francou, B., 1998. A 25,000-year tropical climate history from Bolivian ice cores. Science 282, 1858-1864.

Vallelonga, P., Gabrielli, P., Rosman, K.J.R., Barbante, C., Boutron, C.F., 2005. A 220 kyr record of Pb isotopes at Dome C Antarctica from analyses of the EPICA ice core. Geophys. Res. Lett. 32.

Van de Velde, K., Vallelonga, P., Candelone, J.P., Rosman, K.J.R., Gaspari, V., Cozzi, G., Barbante, C., Udisti, R., Cescon, P., Boutron, C.F., 2005. Pb isotope record over one century in snow from Victoria Land, Antarctica. Earth Planet Sci. Lett. 232, 95-108.

Van Den Bogaard, C., Schmincke, H.U., 2002. Linking the North Atlantic to central Europe: a highresolution Holocene tephrochronological record from northern Germany. J. Quat. Sci. 17, 3-20.

Viccaro, M., Cristofolini, R., 2008. Nature of mantle heterogeneity and its role in the short-term geochemical and volcanological evolution of Mt. Etna (Italy). Lithos 105, 272-288.

Walder, A.J., Abell, I.D., Platzner, I., Freedman, P.A., 1993. Lead Isotope Ratio Measurement of Nist 610 Glass by Laser Ablation Inductively Coupled Plasma Mass-Spectrometry. Spectroc. Acta Pt. BAtom. Spectr. 48, 397-402.

Wanner, H., Beer, J., Butikofer, J., Crowley, T.J., Cubasch, U., Fluckiger, J., Goosse, H., Grosjean, M., Joos, F., Kaplan, J.O., Kuttel, M., Muller, S.A., Prentice, I.C., Solomina, O., Stocker, T.F., Tarasov, P., Wagner, M., Widmann, M., 2008. Mid- to Late Holocene climate change: an overview. Quat. Sci. Rev. 27, 1791-1828.

Wedepohl, K.H., 1995. The composition of the continental-crust. Geochim. Cosmochim. Acta 59, 12171232.

Weiss, D.J., Kober, B., Dalgopolova, A., Gallagher, K., Spiro, B., Le Roux, G., Mason, T.F.D., Kylander, M., Coles, B.J., 2004. Accurate and precise $\mathrm{Pb}$ isotope environmental samples by ratio measurements in MC-ICP-MS. Int. J. Mass Spec. 232, 205-215.

White, W.M., Albarède, F., Telouk, P., 2000. High-precision analysis of Pb isotope ratios by multicollector ICP-MS. Chem. Geol. 167, 257-270. 
652 Wittig, N., Baker, J.A., Downes, H., 2007. U-Th-Pb and Lu-Hf isotopic constraints on the evolution of subcontinental lithospheric mantle, French Massif Central. Geochim. Cosmochim. Acta 71, 12901311.

Zhang, M., Stephenson, P.J., O'Reilly, S.Y., McCulloch, M.T., Norman, M., 2001. Petrogenesis and geodynamic implications of late Cenozoic basalts in North Queensland, Australia: Trace-element and $\mathrm{Sr}-\mathrm{Nd}-\mathrm{Pb}$ isotope evidence. J. Petrol. 42, 685-719.

Zheng, J.C., Shotyk, W., Krachler, M., Fisher, D.A., 2007. A 15,800-year record of atmospheric lead deposition on the Devon Island Ice Cap, Nunavut, Canada: Natural and anthropogenic enrichments, isotopic composition, and predominant sources. Glob. Biogeochem. Cy. 21., GB2027. 
Table 1. Name, location, geographical division and geological setting of the peat cores used in this study. Included in the description of the cores is the basal age of the core and the instrumentation used in $\mathrm{Pb}$ isotope and elemental determinations

\begin{tabular}{|c|c|c|c|c|c|c|}
\hline Location & Core ID & Location & $\begin{array}{l}\text { Calibrated } \\
\text { Basal Age } \\
\text { (Cal. Year) }\end{array}$ & Surrounding bedrock & $\begin{array}{l}\mathrm{Pb} \text { Isotope } \\
\text { Measure. }\end{array}$ & Reference \\
\hline \multicolumn{7}{|l|}{ Ombrotrophic deposits } \\
\hline Store Mosse, Sweden & SM & $57^{\circ} 15^{\prime} \mathrm{N}, 13^{\circ} 55^{\prime} \mathrm{E}$ & 6000 B.C. & Granite, Precambrian & Q-ICP-MS & Brännvall et al, 1999 \\
\hline Trolls Mosse, Sweden & TM & $57^{\circ} 40^{\prime} \mathrm{N}, 14^{\circ} 30^{\prime} \mathrm{E}$ & 5782 B.C. & Granite, Precambrian & Q-ICP-MS & \\
\hline Önneby Mosse, Sweden & $\mathrm{OM}$ & $60^{\circ} 07^{\prime} \mathrm{N}, 13^{\circ} 02^{\prime} \mathrm{E}$ & 3551 B.C. & Granite, Precambrian & Q-ICP-MS & \\
\hline Dumme Mosse, Sweden & $\mathrm{DM}$ & $57^{\circ} 30^{\prime} \mathrm{N}, 14^{\circ} 02^{\prime} \mathrm{E}$ & 2666 B.C. & Granite, Precambrian & Q-ICP-MS & Klaminder et al., 2003 \\
\hline Årshultsmyren, Sweden & $\mathrm{AM}$ & $56^{\circ} 45^{\prime} \mathrm{N}, 13^{\circ} 25^{\prime} \mathrm{E}$ & 4789 B.C. & Gneiss, Precambrian & Q-ICP-MS & \\
\hline Traneröd Mosse, Sweden & $\operatorname{TrM}$ & $56^{\circ} 03^{\prime} \mathrm{N}, 13^{\circ} 11^{\prime} \mathrm{E}$ & 4385 B.C. & Gneiss, Precambrian & Q-ICP-MS & \\
\hline Etang de la Gruère, Switzerland & EGR & $47^{\circ} 23^{\prime} \mathrm{N}, 7^{\circ} 1^{\prime} \mathrm{E}$ & 12508 B.C. & $\begin{array}{l}\text { Carbonate sedimentary } \\
\text { rock, Mesozoic }\end{array}$ & TIMS & Shotyk et al., 2001 \\
\hline Penido Vello, Spain & $\mathrm{PVO}$ & $43^{\circ} 32^{\prime} \mathrm{N}, 7^{\circ} 35^{\prime} \mathrm{W}$ & 6143 B.C. & Granite, Paleozoic & MC-ICP-MS & Kylander et al., 2005 \\
\hline Point d'Escuminac, Canada & $\mathrm{PeW}$ & $45^{\circ} 55^{\prime} \mathrm{N}, 65^{\circ} 30^{\prime} \mathrm{W}$ & 1635 A.D. & Sandstone, Mesozoic & MC-ICP-MS & Kylander et al., 2009 \\
\hline PbR2, Chile & PB & $53^{\circ} 58^{\prime} \mathrm{S}, 70^{\circ} 58^{\prime} \mathrm{W}$ & 12500 B.C. & $\begin{array}{l}\text { Schists, Precambrian to } \\
\text { Paleozoic }\end{array}$ & Q-ICP-MS & $\begin{array}{l}\text { Bindler and Biester, } \\
\text { unpublished }\end{array}$ \\
\hline Sky1, Chile & SKY & $52^{\circ} 30^{\prime} \mathrm{S}, 72^{\circ} 07^{\prime} \mathrm{W}$ & 5000 B.C & $\begin{array}{l}\text { Schists, Precambrian to } \\
\text { Paleozoic }\end{array}$ & Q-ICP-MS & \\
\hline \multicolumn{7}{|l|}{ Minerotrophic deposits } \\
\hline Lynch's Crater, Australia & LyC & $17^{\circ} 37^{\prime} \mathrm{S}, 145^{\circ} 70^{\prime} \mathrm{E}$ & 52 kys B.P. & Basalt, Cenozoic & MC-ICP-MS & Kylander et al., 2007 \\
\hline La Perge, France & $\mathrm{PE}^{* 1}$ & $45^{\circ} 22^{\prime} \mathrm{N}, 01^{\circ} 06^{\prime} \mathrm{E}$ & 3943 B.C. & $\begin{array}{l}\text { Carbonate sedimentary } \\
\text { rock, Cenozoic }\end{array}$ & Q-ICP-MS & Alfonso et al., 2001 \\
\hline St. Ciers-sur-Gironde, France & $\mathrm{CG}^{*^{2}}$ & $45^{\circ} 21^{\prime} \mathrm{N}, 00^{\circ} 39^{\prime} \mathrm{E}$ & 2871 B.C. & $\begin{array}{l}\text { Carbonate sedimentary } \\
\text { rock, Cenozoic }\end{array}$ & Q-ICP-MS & \\
\hline
\end{tabular}

* Core HO 9206b in the original publication

$*^{2}$ Core HO $9608 b$ in the original publication 
Table 2. Summary of average $\mathrm{Pb}$ isotope ratios and $\mathrm{Pb}$ concentrations of the pre-contamination peat and ice (all errors given as $2 \sigma$ ). Minerotrophic sections have been removed from the base of all ombrotrophic cores. Note that $\mathrm{n}=207$ for ${ }^{206} \mathrm{~Pb} /{ }^{204} \mathrm{~Pb},{ }^{207} \mathrm{~Pb} /{ }^{204} \mathrm{~Pb}$ and ${ }^{208} \mathrm{~Pb} /{ }^{204} \mathrm{~Pb}, \mathrm{n}=300 \mathrm{for}{ }^{206} \mathrm{~Pb} /{ }^{207} \mathrm{~Pb}$ average ratios while $\mathrm{n}=295$ for concentration measurements in peat. Also shown are estimates of the UCC commonly used as a proxy for natural $\mathrm{Pb}$.

\begin{tabular}{|c|c|c|c|c|c|c|c|c|}
\hline & Site & $n$ & ${ }^{206} \mathrm{~Pb} /^{204} \mathrm{~Pb}$ & ${ }^{207} \mathrm{~Pb} /{ }^{204} \mathrm{~Pb}$ & ${ }^{208} \mathrm{~Pb}{ }^{204} \mathrm{~Pb}$ & ${ }^{206} \mathrm{~Pb} /^{207} \mathrm{~Pb}$ & $\begin{array}{l}(P b) \\
\left(\mu g g^{-1}\right)\end{array}$ & $\begin{array}{l}\text { Available }{ }^{206} \mathrm{~Pb} /^{207} \mathrm{~Pb} \\
\text { data for local inputs }\end{array}$ \\
\hline \multirow{7}{*}{ 王 } & Dome C & 30 & $18.787 \pm 1.033$ & $15.526 \pm 0.856$ & $38.465 \pm 2.155$ & $1.210 \pm 0.032$ & $0.0067 \pm 0.015$ & \\
\hline & Devon Island & 14 & - & - & - & $1.230 \pm 0.079$ & $0.0000273 \pm 0.0000973$ & \\
\hline & GRIP & $5^{1}$ & $18.714 \pm 0.165$ & $15.579 \pm 0.133$ & $38.664 \pm 0.384$ & $1.201 \pm 0.005$ & $0.0014 \pm 0.0058$ & \\
\hline & & $24^{2}$ & $18.751 \pm 0.521$ & $15.639 \pm 0.363$ & $38.679 \pm 0.910$ & $1.199 \pm 0.019$ & $0.0000347 \pm 0.0000674$ & \\
\hline & Saiama Mountain & & $18.05 \pm 0.15$ & & & $1.1544 \pm 0.0030$ & 0.000149 & \\
\hline & sajama viountain & & $18.03 \pm 0.06$ & & & $1.1607 \pm 0.0019$ & 0.000102 & \\
\hline & Mean for ice records & & $18.742 \pm 0.832$ & $15.576 \pm 0.657$ & $38.569 \pm 1.645$ & $1.208 \pm 0.049$ & $0.001 \pm 0.005$ & \\
\hline \multirow{20}{*}{$\underset{E}{E}$} & $\mathrm{PbR} 2$, Chile & 25 & $18.650 \pm 0.355$ & $15.630 \pm 0.266$ & $38.655 \pm 0.813$ & $1.193 \pm 0.015$ & $1.93 \pm 4.55$ & \\
\hline & Sky1, Chile & 6 & $18.522 \pm 0.531$ & $15.634 \pm 0.211$ & $38.613 \pm 0.913$ & $1.185 \pm 0.028$ & $1.18 \pm 2.48$ & \\
\hline & Lynch's Crater, Australia & 100 & $18.833 \pm 0.376$ & $15.668 \pm 0.037$ & $38.895 \pm 0.425$ & $1.202 \pm 0.022$ & $0.77 \pm 0.68$ & $\begin{array}{l}\text { Soil: } 1.20,1.24^{3} \\
\text { Rock: } 1.18-1.29^{3}\end{array}$ \\
\hline & Point d'Escuminac, Canada & 22 & $18.620 \pm 0.102$ & $15.643 \pm 0.033$ & $38.565 \pm 0.212$ & $1.190 \pm 0.005$ & $0.68 \pm 0.53$ & \\
\hline & Penido Vello, Spain ${ }^{\mathrm{a}}$ & 27 & $19.803 \pm 1.007$ & $15.714 \pm 0.067$ & $38.444 \pm 0.386$ & $1.260 \pm 0.059$ & $3.2 \pm 4.7$ & Rock : $1.33^{4}$ \\
\hline & Etang de la Gruère, Switzerland & 27 & $18.798 \pm 0.152$ & $15.652 \pm 0.049$ & $38.718 \pm 0.174$ & $1.200 \pm 0.008$ & $0.38 \pm 0.04$ & Soil: $1.22-1.24^{5}$ \\
\hline & St. Ciers-sur-Gironde, France & 5 & - & - & - & $1.198 \pm 0.004$ & $9.1 \pm 17.6$ & Soil: $1.185^{6}$ \\
\hline & La Perge, France & 10 & - & - & - & $1.193 \pm 0.011$ & $4.5 \pm 4.2$ & \\
\hline & Årshultsmyren, Sweden & 23 & - & - & - & $1.211 \pm 0.045$ & $0.080 \pm 0.081$ & Soil: $1.46^{7}$ \\
\hline & Traneröd Mosse, Sweden & 22 & - & - & - & $1.196 \pm 0.047$ & $0.24 \pm 0.049$ & Soil: $1.32-1.33^{7}$ \\
\hline & Dumme Mosse, Sweden & 8 & - & - & - & $1.215 \pm 0.034$ & $0.054 \pm 0.058$ & Soil: $1.33^{7}$ \\
\hline & Trolls Mosse, Sweden & 5 & - & - & - & $1.226 \pm 0.051$ & $0.30 \pm 0.91$ & Soil: $1.30-1.32^{8}$ \\
\hline & Store Mosse, Sweden & 12 & - & - & - & $1.205 \pm 0.060$ & $0.43 \pm 1.38$ & Soil: $1.33^{8}$ \\
\hline & Önneby Mosse, Sweden & 8 & - & - & - & $1.238 \pm 0.044$ & $0.10 \pm 0.05$ & Soil: $1.38^{8}$ \\
\hline & Mean for peat records & & $18.90 \pm 0.86$ & $15.66 \pm 0.10$ & $38.74 \pm 0.57$ & $1.21 \pm 0.05$ & $1.2 \pm 4.5$ & \\
\hline & $\mathrm{UCC}^{9}$ & & $18.93 / 19.07$ & $15.71 / 15.74$ & $39.03 / 39.35$ & $1.205 / 1.212$ & & \\
\hline & $\mathrm{UCC}^{10}$ & & 19.22 & 15.78 & 39.58 & 1.218 & & \\
\hline & $\mathrm{UCC}^{11}$ & & 19.32 & 15.76 & 39.33 & 1.226 & & \\
\hline & $\mathrm{UCC}^{12}$ & & $18.68-19.11$ & $15.66-15.70$ & $38.58-39.47$ & $1.19-1.22$ & & \\
\hline & $\mathrm{UCC}^{13}$ & & & & & & 17 & \\
\hline
\end{tabular}


${ }^{3}$ Kylander et al., 2007; Zhang et al., 2001; ${ }^{4}$ Kylander et al., 2005; ${ }^{5}$ Nowack et al., 2001; ${ }^{6}$ Semlali et al., 2001; ${ }^{7}$ Klaminder et al., 2003; ${ }^{8}$ Brännvall et al., 1999 ; ${ }^{9}$ Millot, et al., 2004; ${ }^{10}$ Hemming and McLennan, 2001; ${ }^{11}$ Asmerom and Jacobsen, 1993; ${ }^{12}$ Kramers and Tolstikhim, 1997; ${ }^{13}$ Wedepohl, 1995.

${ }^{a}$ The definition of the natural background was changed from the original publication to include the entire pre-contamination ombrotrophic section , the two large excursion were not removed 


\section{Figure Captions}

Figure 1. World map showing the geographical location of the discussed cores and the average pre-contamination ${ }^{206} \mathrm{~Pb} /{ }^{207} \mathrm{~Pb}$ ratio in the aerosol. The pre-contamination period used in these calculations ranges from 150 years (PeW) to 220 kyrs (DC).

Figure 2. Temporal variations in the ${ }^{206} \mathrm{~Pb} /{ }^{207} \mathrm{~Pb}$ ratio in the studied peat bog archives from Europe. The six sites from southern Sweden (line) are plotted together as a fivepoint running mean (thick black line). Dashed line indicates a period of $10{ }^{206} \mathrm{~Pb} /{ }^{207} \mathrm{~Pb}$ ratios that appear to co-occur. It is unclear if this event is recorded in Switzerland.

Figure 3. Three-isotope plots of ${ }^{206} \mathrm{~Pb} /{ }^{207} \mathrm{~Pb}$ vs. ${ }^{208} \mathrm{~Pb} /{ }^{206} \mathrm{~Pb}$ using available data from the pre-contamination sections in the studied peat bogs and their generalized fields. Dashed lines represent ranges of published UCC estimates (see Table 2 for references). Symbols for each site are indicated in the right hand panel. Note that only ${ }^{206} \mathrm{~Pb} /{ }^{207} \mathrm{~Pb}$ data is available for three of the Swedish sites, ranges shown at the bottom of the plot.

Figure 4. Three-isotope plots of ${ }^{207} \mathrm{~Pb} /{ }^{204} \mathrm{~Pb}$ vs. ${ }^{206} \mathrm{~Pb} /{ }^{204} \mathrm{~Pb}$ (a) and ${ }^{208} \mathrm{~Pb} /{ }^{204} \mathrm{~Pb}$ vs. ${ }^{206} \mathrm{~Pb} /{ }^{204} \mathrm{~Pb}$ (b) using available data from the pre-contamination sections in the studied peat bogs and their generalized fields. Dashed lines represent ranges of published UCC estimates (see Table 2 for references). Symbols for each site are indicated in the right hand panel.

Figure 5. Three-isotope plots of ${ }^{206} \mathrm{~Pb} /{ }^{207} \mathrm{~Pb}$ vs. ${ }^{208} \mathrm{~Pb} /{ }^{206} \mathrm{~Pb}$ using available data from the pre-contamination sections in the studied peat bogs and generalized fields of possible natural $\mathrm{Pb}$ sources which include mineral dusts (as represented by ocean sediments and loess deposits), crustal sources (as represented by river sediments) and volcanic sources (as represented by volcanic rocks)(see text for references). Dashed lines represent ranges of published UCC estimates (see Table 2 for references). Symbols for each site are indicated in the right panel.

Figure 6. Three-isotope plots of ${ }^{207} \mathrm{~Pb} /{ }^{204} \mathrm{~Pb}$ vs. ${ }^{206} \mathrm{~Pb} /{ }^{204} \mathrm{~Pb}$ (a) and ${ }^{208} \mathrm{~Pb} /{ }^{204} \mathrm{~Pb}$ vs. ${ }^{206} \mathrm{~Pb} /{ }^{204} \mathrm{~Pb}$ (b) using available data from the pre-contamination sections in the studied peat bogs and generalized fields of possible natural $\mathrm{Pb}$ sources which include mineral dusts (as represented by ocean sediments and loess deposits), crustal sources (as represented by river sediments) and volcanic sources (as represented by volcanic rocks)(see text for references). Dashed lines represent ranges of published UCC estimates (see Table 2 for references). Symbols for each site are indicated in the right panel. 
Kylander et al.- Fig 1

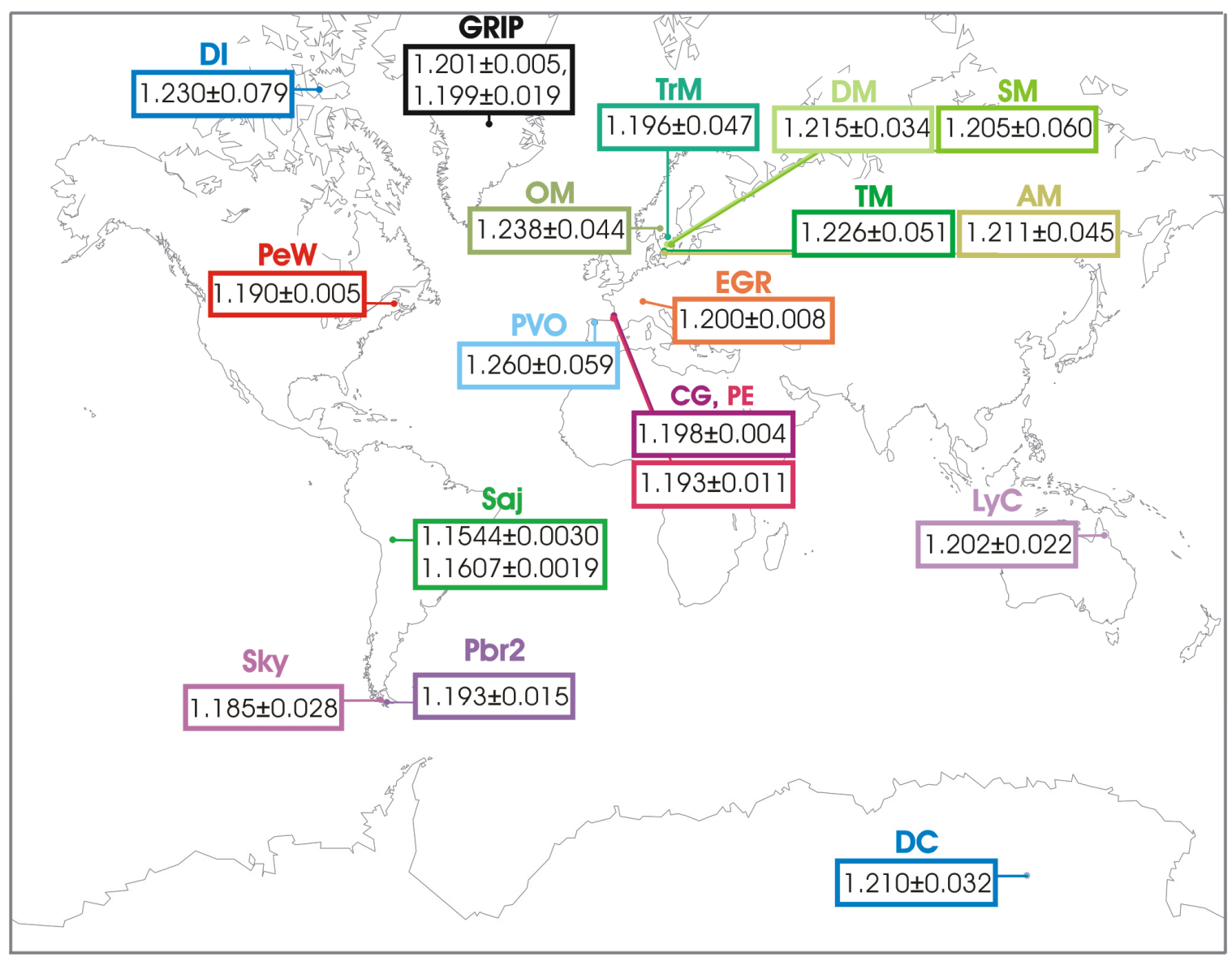


Kylander et al.- Fig 2

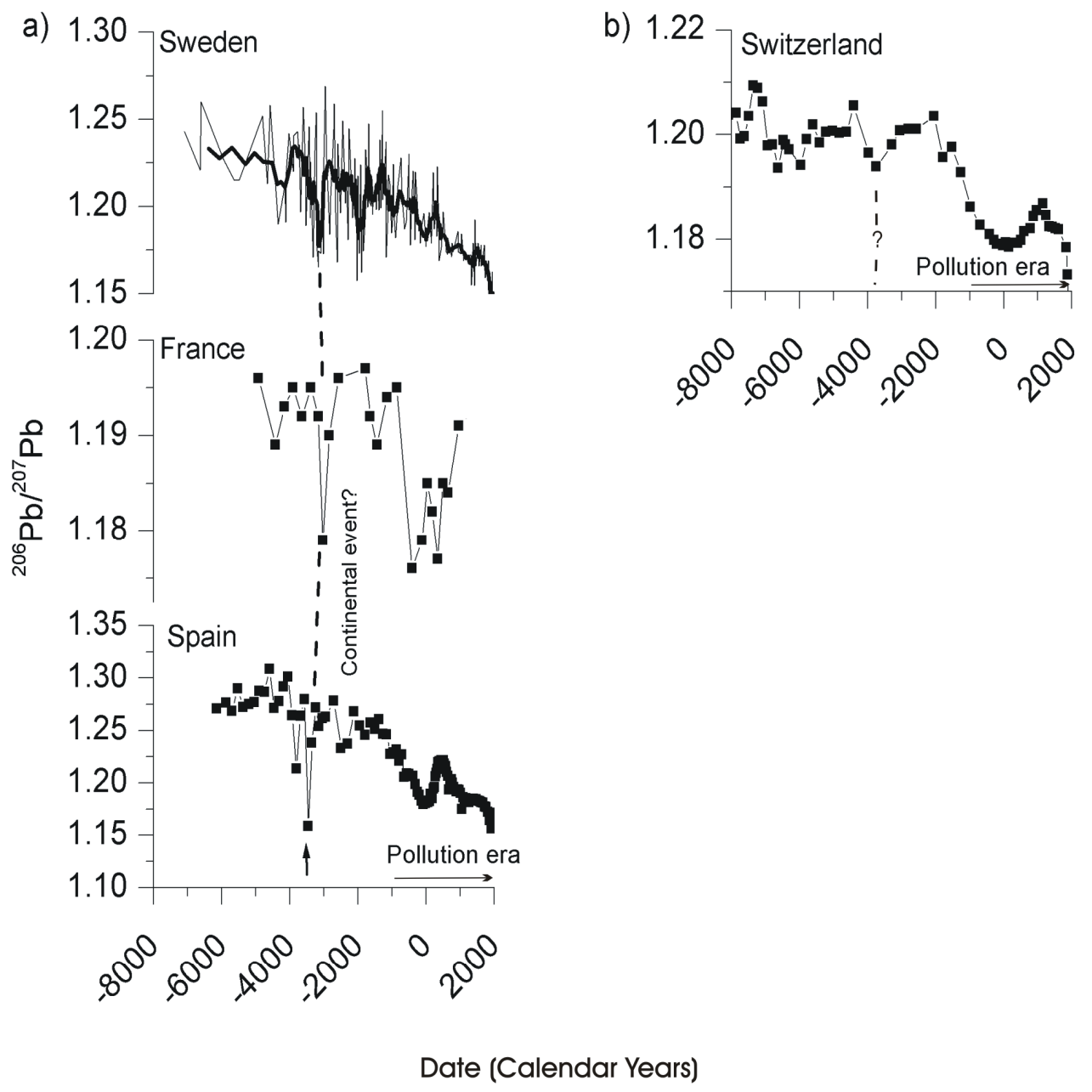


Kylander et al.-Fig 3

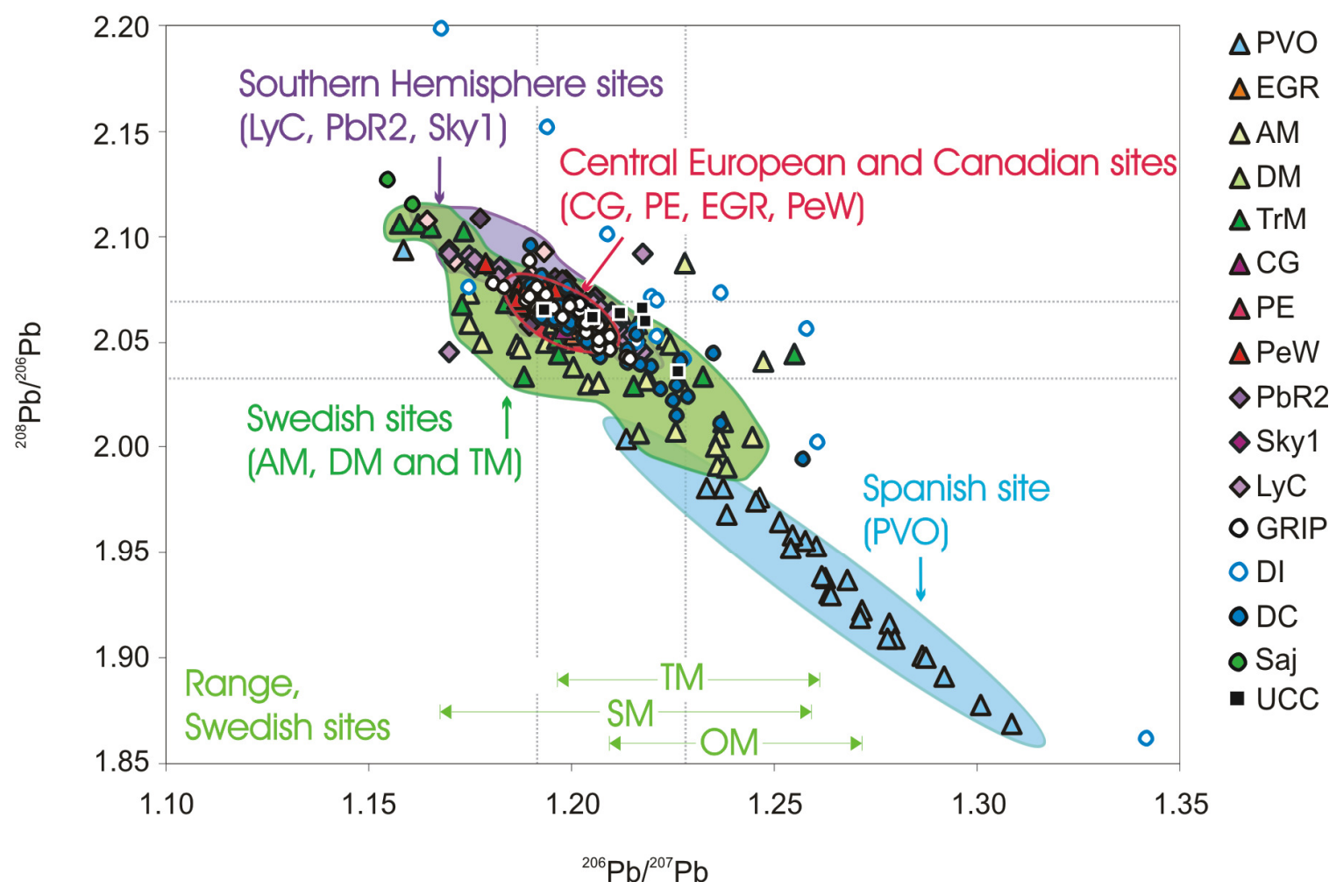


Kylander et al.-Fig 4

a.

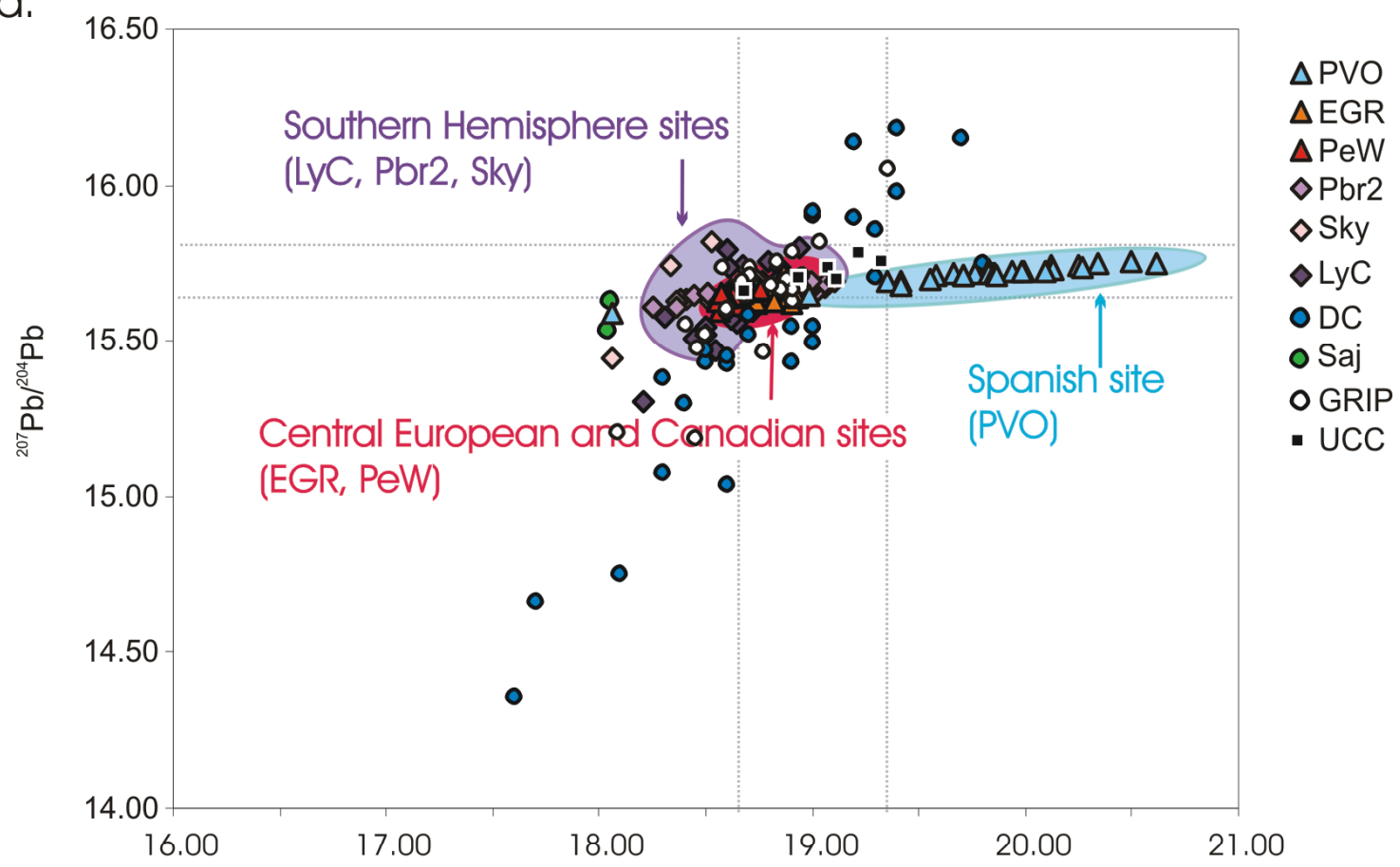

b.

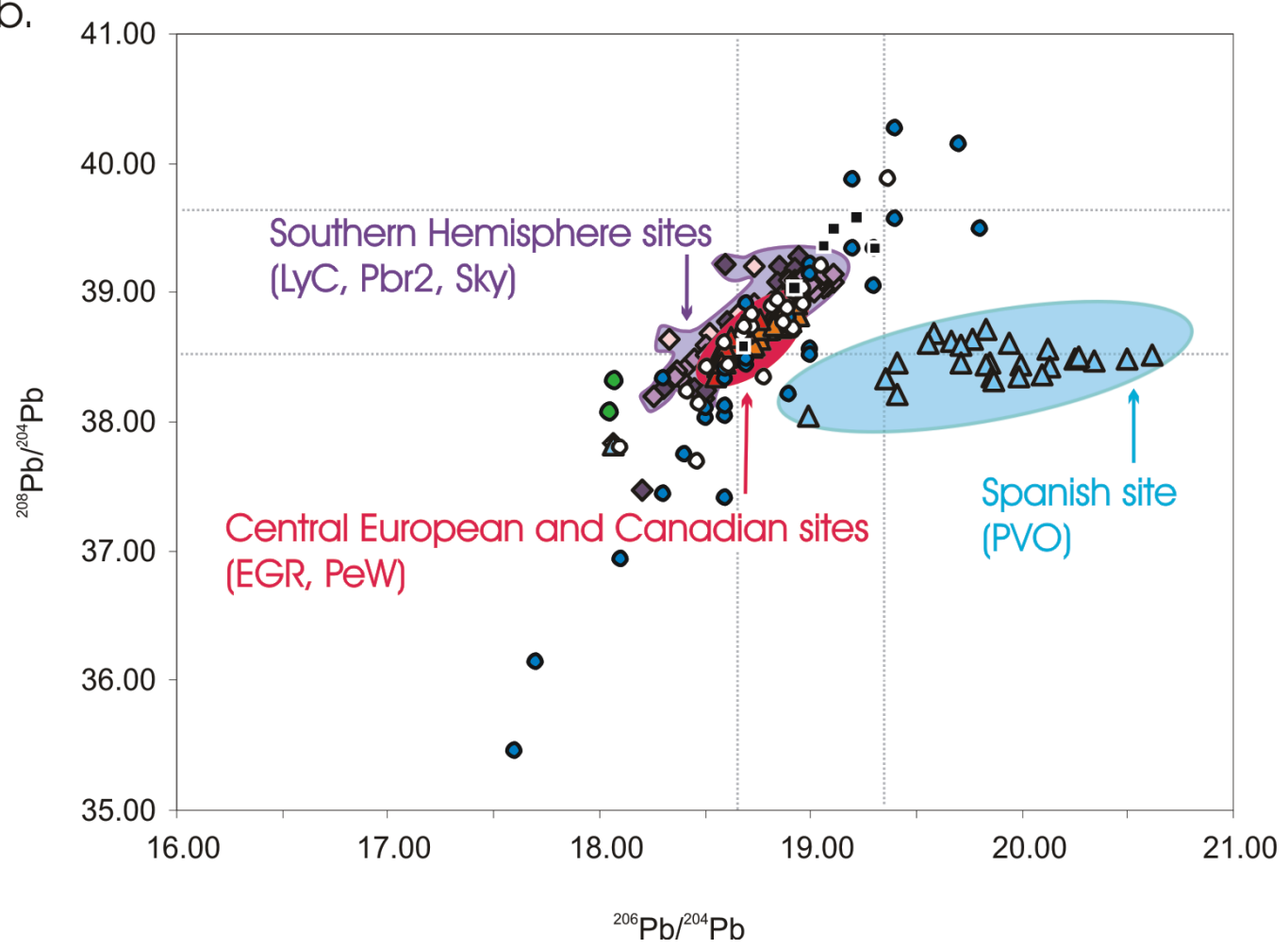


Kylander et al.-Fig 5

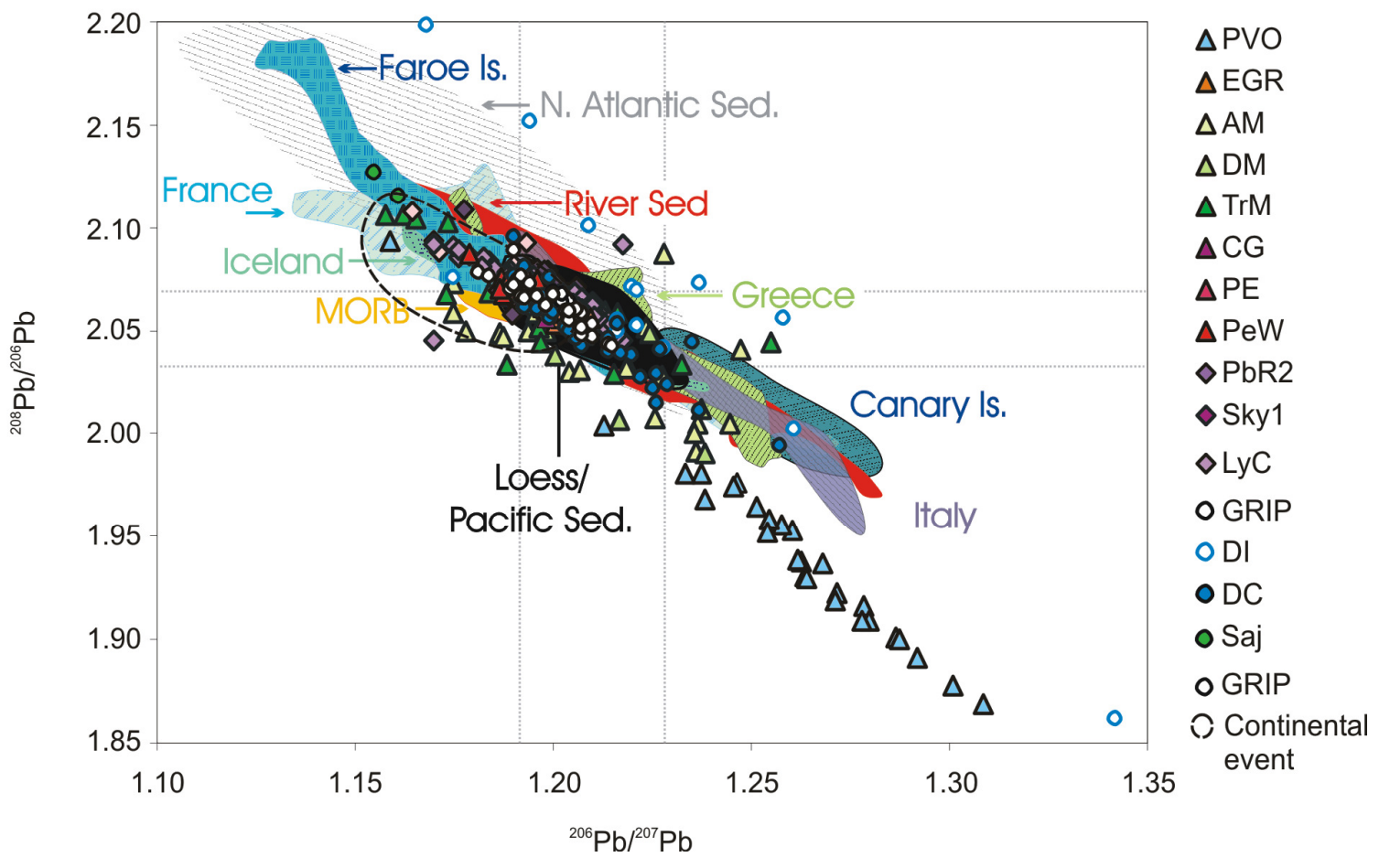


Kylander et al.-Fig 6

a.

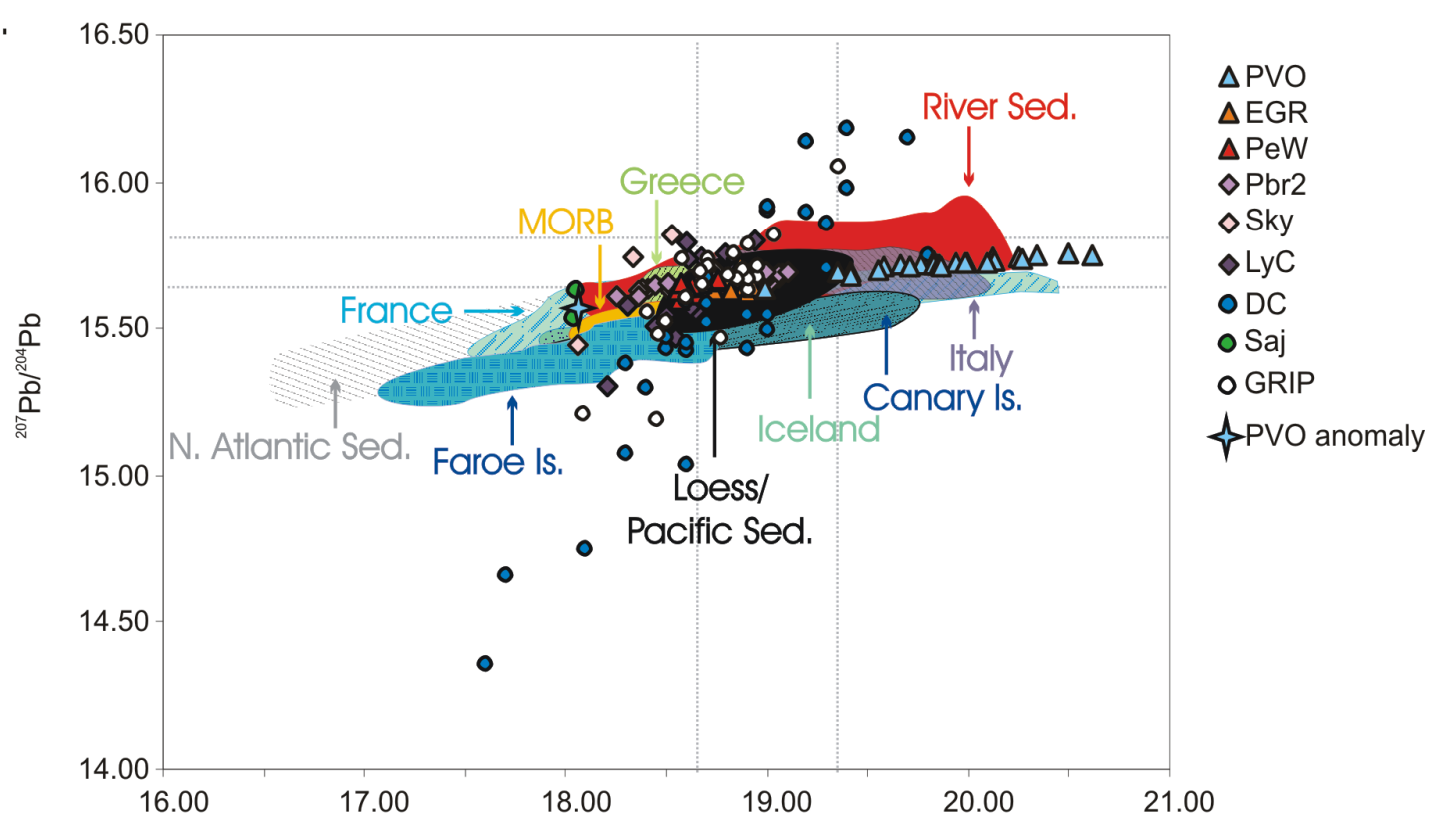

b.

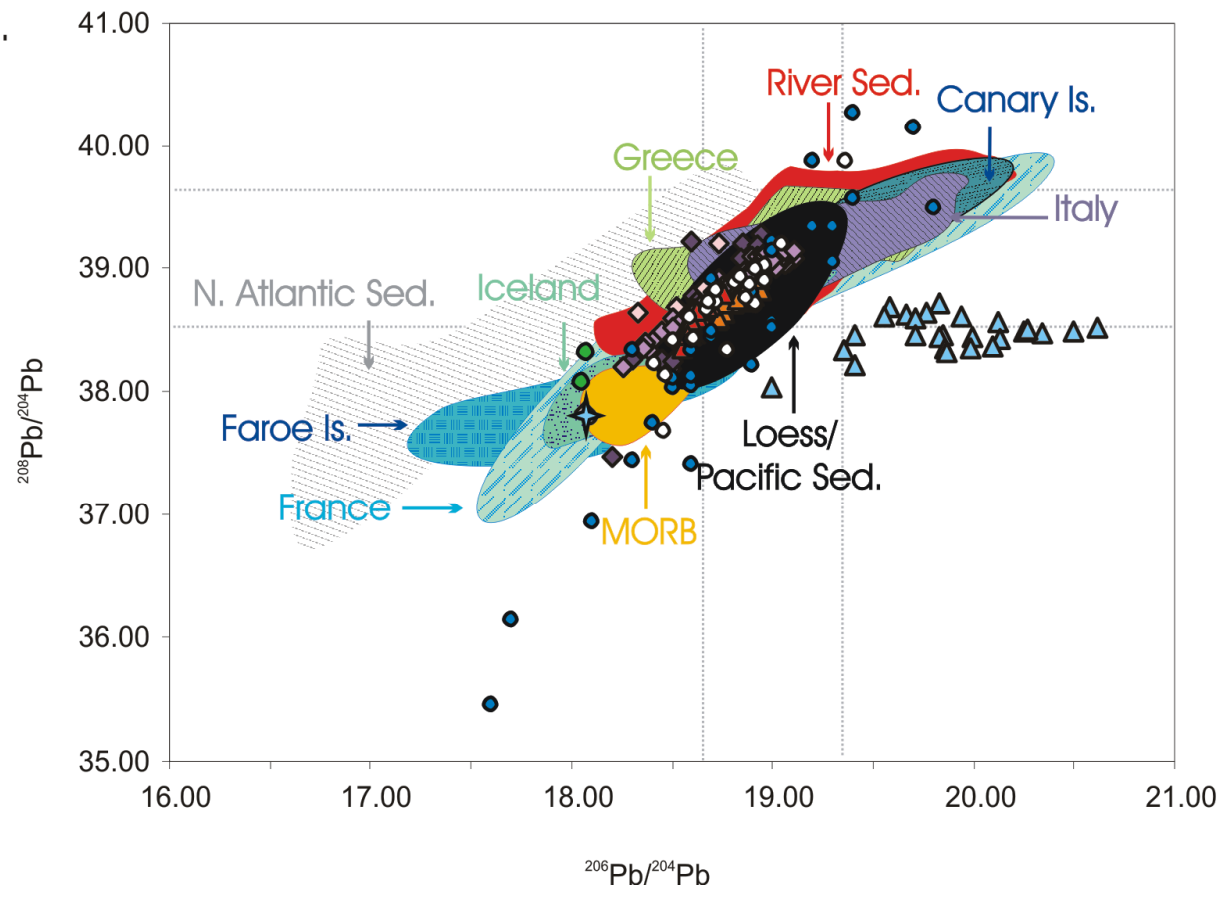

